DMD 5280

\title{
Inhibition of Lung Cancer Cell Growth by Quercetin Glucuronides via G2/M Arrest and Induction of Apoptosis
}

Jen-Hung Yang, Department of Dermatology, Chung Shan Medical University Hospital, Taichung,

Taiwan 402; Te-Chun Hsia, Department of Internal Medicine, China Medical University Hospital,

Taichung, Taiwan 404; Hsiu-Maan Kuo, Department of Parasitology, China Medical University,

Taichung, Taiwan 404; Pei-Daen Lee Chao, Department of Pharmacy, China Medical University,

Taichung, Taiwan 404; Chi-Chung Chou, Department of Veterinary Medicine, National Chung-Hsin

University, Taichung, Taiwan 402; Yau-Huei Wei, Department of Biochemistry, National Yang-Ming

University, Taipei, Taiwan 112; Jing-Gung Chung, School of Biological Science and Technology,

China Medical University, Taichung, Taiwan 404, Republic of China 
DMD 5280

Running Title:

\section{Quercetin induce G2/M arrest and apoptosis in lung cancer cells}

Corresponding author: Jing-Gung Chung, Ph.D.;

Department of Microbiology, China Medical University, No 91, Hsueh-Shih Road,

Taichung 404, Taiwan, Republic of China

Tel: 886-4-2205-3366-8501, Fax: 886-4- 2205-3764,

E-mail: jgchung@mail.cmu.edu.tw

Document Statistics:

The article contains 20 text pages (Abstract, Introduction, materials \& Methods,

Results and Discussion), 1 table, 8 figures, 50 references, and the words in the

Abstract is 247, words in the Introduction is 474, and words in the Discussion is 1183.

\section{Abbreviations:}

PARP: poly-(ADP-ribose) polymerase; SCLC: small-cell lung carcinoma;

ROS: reactive oxygen species; z-VAD-fmk: Benzyloxycarbonyl-Val-Ala-Asp

fluoromethylketone 
DMD 5280

\section{Abstract}

Lung cancer is the leading cause of cancer death in many developed countries including Taiwan. Quercetin, a widely distributed bioflavonoid, is well known to induce growth inhibition in a variety of human cancer cells. Quercetin glucuronides are the main circulating metabolites after dietary supplement with quercetin in humans. However, there is little information available as to how quercetin glucuronides affect human cancer cells. We investigated the effects of quercetin glucuronides in a human lung cancer cell line NCI-H209. We checked the cell viability, cell cycle checkpoint proteins, pro- and anti-apoptotic proteins, caspases-3 activity; and gene expression by flow cytometry and Western blot. The viability of cells decreased in a dose- and time-dependent manner. Cell cycle analysis revealed a significant increase of proportion of cells in G2/M phase and sub-G0/G1 phase (corresponding to apoptotic cells). Moreover, quercetin glucuronides increased the expressions of cylin B, Cdc25c-ser-216-p and Wee1 proteins, indicating the G2/M arrest. We also demonstrated a concurrent decrease of the mitochondrial membrane potential, release of cytochrome $c$, up-regulation of Bax, down-regulation of Bcl-2, and activation of caspase-3, subsequently cleavage of poly-(ADP-ribose) polymerase

(PARP). In addition, quercetin glucuronides-induced apoptosis was totally blocked by the broad-spectrum caspase inhibitor, z-VAD-fmk. Taken together, we 
DMD 5280

demonstrated that quercetin glucuronides inhibited proliferation through G2/M arrest

of the cell cycle and induced apoptosis via caspase-3 cascade in the human lung cancer cell line NCI-H209. Delineation of the biological effects of specific major quercetin metabolites on chemotherapeutic potential or chemoprevention of human cancers warrants further investigation. 
DMD 5280

\section{INTRODUCTION}

Lung cancer is the leading cause of cancer death in many developed countries, including Taiwan, in which $20 \%$ of cancer deaths have been caused by lung cancer(Greenlee et al, 2000). Small-cell lung carcinoma (SCLC), a form of lung cancer characterized by a neuroendocrine phenotype, represents about $20 \%$ of primary lung cancers and exhibits the most malignant phenotype of lung cancer (Chua et al, 2004). Most SCLC patients are not suitable for surgery, and the standard treatment for SCLC is chemotherapy or radiotherapy (Chua et al, 2004); however, the treatment outcome of SCLC or other types of lung cancer is far from satisfactory.

Flavonoids are naturally occurring polyphenolic compounds and have profound pharmacological properties and a daily intake of flavonoids is associated with a lower risk of cancer (Middleton et al, 2000). Quercetin (3,3',4',5,7-pentahydroxyflavone) is one of the major dietary flavonoids particularly abundant in fruits and vegetables (Hertog et al, 1993). Analysis of plasma of volunteers fed with quercetin supplemented diet shows that quercetin is mainly circulating as quercetin glucuronides (Fig. 1) (Manach et al, 2004). Most of the biological studies for assessing the properties of quercetin are performed on quercetin (aglycone), and there 
DMD 5280

is limited information available regarding the biological effects of quercetin glucuronides.

Quercetin has been shown to have diverse biological activities, including anti-proliferative and apoptotic effects (Choi et al, 2001), although the mechanisms are still obscure. Quercetin treatment caused cell cycle arrest either at the $\mathrm{G}_{1} / \mathrm{S}$ or $\mathrm{G}_{2} / \mathrm{M}$ transition depending on cell type (Choi et al, 2001; Nguyen et al, 2004; Ong et al, 2004). Moreover, quercetin-mediated apoptosis may be related to many factors such as stress proteins, disruption of microtubules, NF- $\kappa \mathrm{B}$, Cox-2, p53, survivin, JNK, MEK-ERK, Bcl-2 family proteins, heat shock proteins, DNA topoisomerase II, release of cytochrome c, and activation of caspases (Yoshida et al, 1990; Orzechowski et al, 2000; Choi et al, 2001; Jakubowicz-gil et al, 2002; Kaneuchi et al, 2003; Nguyen et al, 2004; Ong et al, 2004; Cheong et al, 2004; Kuo et al, 2004). Quercetin has been reported to inhibit the growth of various human cancers, including leukemia, breast, esophagus, colon, prostate, nasopharyngeal, endometrial, and lung cancers (Yoshida et al, 1990; Orzechowski et al, 2000; Choi et al, 2001; Jakubowicz-gil et al, 2002; Kaneuchi et al, 2003; Nguyen et al, 2004; Ong et al, 2004; Cheong et al, 2004;

Kuo et al, 2004). It is imperative to investigate the biological effects of quercetin glucuronides that are more close to the in vivo situation. Although quercetin-induced apoptosis has been documented in human lung cancer cells 
DMD 5280

(Nguyen et al, 2004; Kuo et al, 2004), there are no reports addressing the molecular mechanisms of quercetin glucuronides-induced apoptosis in human lung cancer cells. Here, we report the findings that quercetin glucuronides inhibited cell proliferation through cell cycle arrest and induction of apoptosis in human lung cancer NCI-H209 cells.

\section{METHODS}

Materials. Quercetin, catalase, ribonuclease-A, trypan blue, Tris-HCl, Triton X-100, propidium iodide (PI) were obtained from Sigma Chemical Co. (St. Louis, MO, USA). Potassium phosphate, dimethyl sulfoxide (DMSO), and Trizma base were purchased from Merck Co. (Darmstadt, Germany). F12K medium, penicillin-streptomycin, trypsin-EDTA, fetal bovine serum (FBS), and glutamine were obtained from Gibco BRL (Grand Island, NY, USA). Caspase-3 activity assay kit was purchased from Boehringer Mannheim (Mannhein, Germany).

Preparation of Quercetin Glucuronides. Quercetin glucuronides were prepared from the serum of rabbits which were administrated with quercetin and the concentration of quercetin glucuronides was determined by HPLC after hydrolysis with $\beta$-glucuronidase as described previously (Wittig et al, 2001; Kuo et al, 2002). 
DMD 5280

Human Lung Cancer Cell Line NCI-H209. NCI-H209 is a SCLC cell line procured from The Sanger Institute, and we purchased it from the Food Industry Research and Development Institute (Hsinchu, Taiwan). The cells were immediately transferred into $75 \mathrm{~cm}^{3}$ tissue culture flasks and grown at $37^{\circ} \mathrm{C}$ under a humidified $5 \%$ $\mathrm{CO}_{2}$ and $95 \%$ air at one atmosphere in RPMI 1640 medium supplemented with $10 \%$ FBS, $1 \%$ penicillin-streptomycin $(10 \mathrm{ng} / \mathrm{ml}$ penicillin and $10 \mathrm{ng} / \mathrm{ml}$ streptomycin) and $1 \%$ glutamine.

\section{Cell Viability Determination by Using Trypan Blue Exclusion and Flow}

Cytometry. NCI-H209 cells were plated in 12 -well plates at a density of $5 \times 10^{5}$ cells/well and grown for 24 hours. They were then added with different concentrations of quercetin glucuronides to reach final concentrations of $0,0.5,1,2.5,5$ and $10 \mu \mathrm{M}$, while only adding DMSO (solvent) for the control and grown at $37^{\circ} \mathrm{C}, 5 \% \mathrm{CO}_{2}$ and 95\% air for a different period of time. For determination of cell viability, the trypan blue exclusion protocol was used. Briefly, about $10 \mu \mathrm{l}$ of cell suspensions in PBS were mixed with $40 \mu \mathrm{l}$ of trypan blue, and the numbers of stained (dead cells) and unstained cells (live cells) were counted using a hemocytometer (Pettit et al, 1996) or using flow cytometric assasy as described previously (Lee et al, 2003). 
DMD 5280

\section{Determination of DNA Fragmentation of NCI-H209 Cells by Gel}

Electrophoresis. NCI-H209 cells were plated in 6-well plates at a density of 5x106 cells/well and grown for 24 hours. They were then added with 50 and $100 \mu \mathrm{M}$ quercetin glucuronides as described above while only adding DMSO (solvent) for the control regimen and grown at $37^{\circ} \mathrm{C}$, in a humidified $5 \% \mathrm{CO} 2$ and $95 \%$ air for 48 hours. DNA fragmentation was assessed by electrophoresis assay as described previously. The DNA was prepared using GENOME DNA isolation kit protocol (BIO 101, La Jolla, CA, USA) as described in previous studies (Chung, 1999).

Analysis of DNA Content by Flow Cytometry in NCI-H209 cells. About 5x10 cells/well of NCI-H209 cells in 6-well plate were incubated with concentrations of $(0$, $0.5,1,2.5,5$, and $10 \mu \mathrm{M})$ of quercetin glucuronides were incubated for different time periods, then the cells were harvested by centrifugation. The cells were fixed gently (drop by drop) by putting $70 \%$ ethanol (in PBS) in ice overnight and were then resuspended in PBS containing $40 \mu \mathrm{g} / \mathrm{mL}$ PI and $0.1 \mathrm{mg} / \mathrm{mL}$ RNase (Sigma, St. Louis, MO, USA) and 0/1\% Triton X-100 in dark room. After 30 minutes at $37^{\circ} \mathrm{C}$, the cells were analyzed on a flow-cytometer (Becton-Dickinson, San Jose, CA, USA) equipped with an argon laser at $488 \mathrm{~nm}$ wave-length. The cell cycle was then 
DMD 5280

analyzed (Ormerod, 1990).

\section{Detection of Reactive Oxygen Species (ROS) in NCI-H209 Cells by Flow}

Cytometry. The level of ROS of the NCI-H209 cells was determined by flow cytometry (Becton Dickinson FACS Calibur), using 2,7-Dichlorodihydrofluorescein diacetate(DCFH-DA, Sigma). NCI-H209 cells were treated with or without various concentrations $(0.5,1,2.5,5$ and $10 \mu \mathrm{M})$ of quercetin glucuronides for 24 hours, and the levels of ROS were determined. The cells were harvested and washed twice, re-suspended in $500 \mu \mathrm{l}$ of 2,7-Dichlorodihydrofluorescein diacetate $(10 \mu \mathrm{M})$ and incubated at $37^{\circ} \mathrm{C}$ for $30 \mathrm{~min}$ and analyzed by flow cytometry (Kalbacova et al, 2003).

Detection of Mitochondrial Membrane Potential by Flow Cytometry. The mitochondrial membrane potential of the NCI-H209 cells was determined by flow cytometry (Becton Dickinson FACS Calibur), using the $\mathrm{DiOC}_{6}(4 \mathrm{~mol} / \mathrm{L}) . \quad \mathrm{NCI}-\mathrm{H} 209$ cells were treated with or without various concentrations $(0.5,1,2.5,5$ and $10 \mu \mathrm{M})$ of quercetin glucuronides for 24 hours, and the mitochondrial membrane potential was measured. The cells were harvested and washed twice, re-suspended in $500 \mu \mathrm{l}$ of 
DMD 5280

$\mathrm{DiOC}_{6}(4 \mathrm{~mol} / \mathrm{L})$ ant incubated at $37^{\circ} \mathrm{C}$ for $30 \mathrm{~min}$ and analyzed by flow cytometry

(Kalbacova et al, 2003).

Determination of Caspase-3 Activity in NCI-H209 cells. NCI-H209 cells were

plated in 12-well plates at a density of $5 \times 10^{5}$ cells/well and grown for 24 hours. Various concentrations of quercetin glucuronides were added to the medium and the cells were grown at $37{ }^{\circ} \mathrm{C}$ in a humidified $5 \% \mathrm{CO}_{2}$ for 12 hours. Approximate $5 \times 10^{6}$ cells were lysed in the lysis buffer ( $1 \%$ Triton X-100, $0.32 \mathrm{M}$ sucrose, $5 \mathrm{mM}$ EDTA, 10 mM Tris-HCl, pH 8.0, 2mM dithiothreitol, 1 mM PMSF, $1 \mu \mathrm{g} / \mathrm{ml}$ aprotinin, $1 \mathrm{mg} / \mathrm{ml}$ leupeptin) for 30 minutes at $4^{\circ} \mathrm{C}$ followed by centrifugation at $10,000 \mathrm{xg}$ for 30 minutes. For caspase- 3 activity determination, $50 \mu \mathrm{L}$ reaction mixtures with fluorogenic peptide substrates were specifically used for caspase-3. The peptide substrate $(200 \mu \mathrm{M})$ was incubated at $37^{\circ} \mathrm{C}$ with cytosolic extracts $(15 \mu \mathrm{g}$ of total protein) in the reaction buffer (100 mM HEPES, $10 \%$ sucrose, $10 \mathrm{mM}$ DTT, $0.1 \%$ 3-[3-chloamidopropyl] dimethylammonio-1-propanesulfonate). Fluorescence was determined after 2 hours (excitation wavelength, $400 \mathrm{~nm}$; emission wavelength, 505 $\mathrm{nm}$ ) with a fluorescence plate reader (Fluoroskan Ascent; Labsystems) (Lu et al, 2004). 
DMD 5280

Effect of Caspase Inhibitor z-VAD-fmk on Caspase-3 Activity and Apoptosis.

In order to examine whether or not caspase-3 activation is involved in the apoptosis triggered by quercetin glucuronides. NCI-H209 cells had been pretreated with z-VAD-fmk (a permeable broad-spectrum caspase inhibitor) 3 hours prior to treatment with quercetin glucuronides. Apoptosis and caspase-3 activity were then determined as described above.

Poly-(ADP ribose) Monoclonal Antibody Assay for Apoptosis of NCI-H209 Cells.

NCI-H209 cells were plated in 12 -well plates at a density of $2 \times 10^{5}$ cells/well and grown for 24 hours. Various concentrations of quercetin glucuronides were added to the medium and the cells were grown at $37{ }^{\circ} \mathrm{C}$ in a humidified $5 \% \mathrm{CO}_{2}$ for 24 hours for poly (ADP ribose) monoclonal antibody assay (Alexis, San Diego, CA, USA) as described in previous studies (Ormerod, 1990; Ferreira et al, 2002).

\section{Western Blotting for Examination of Effect of Quercetin Glucuronides on the}

Expression of Apoptosis-related Proteins. Total proteins were collected from

human lung cancer NCI-H209 cells treated with or without various concentrations of quercetin glucuronides for 48 hours. Western blotting were used to examine the expression levels of the apoptosis-related proteins including $\mathrm{p} 21^{\mathrm{CIP} 1 / \mathrm{WAF} 1}$, 
DMD 5280

Cdc25C-ser-216-p (phosphorylation of Cdc25C on serine-216), Bax, Bad, Bcl-2,

Bcl-xl, cytochrome c, caspase-9, caspase-3, and PARP by sodium dodecylsulfate polyacrylamide gel electrophoresis (SDS-PAGE) as previously described (Ferreira et al, 2002).

Statistical Analysis. Student $t$-test was used to analyze the statistical significance of the differences between the quercetin glucuronides-treated and control groups.

\section{RESULTS}

\section{Effects of Quercetin Glucuronides on Cell Viability of Lung Cancer NCI-H209}

cells. For control group, the data indicated that $<2 \%$ of NCI-H209 cells were stained by trypan blue or propidium iodide when they were incubated in medium containing $10 \%$ FBS only. In the presence of quercetin glucuronides $(0.5,1,2.5,5$ and $10 \mu \mathrm{M})$, the dye density of cultured cells was increased by the increase of the time and concentration used, suggesting that quercetin glucuronides exerted a dose-dependent cytotoxic effect on NCI-H209 cells (Figs. 2A and 2B). The IC50 of quercetin glucuronides was approximately $34.8 \mu \mathrm{M}$.

Quercetin Glucuronides Induced Cell Cycle Arrest and Apoptosis in NCI-H209 
DMD 5280

Cells. The data indicated that during the 48 hours time period, quercetin glucuronides did increase the percentage of S and G2/M phases, and the percentage of G0/G1 phase was decreased. Non-treated control cells showed a typical pattern of DNA content that reflected G0/G1-, S- and G2/M- phase of the cell cycle. The quercetin glucuronides-treated cells showed a typical pattern of DNA content that reflected G0/G1-, S- and G2/M- phase of the cell cycle together with a sub-G0/G1phase (corresponding to apoptotic cells) as shown in Figure 3A and 3B. Quercetin glucuronides induced a distinct sub-G1 peak, which represents the population of apoptotic cells. The percentage of apoptosis in various concentrations of quercetin glucuronides are shown in Figure 3C.

Effect of Quercetin Glucuronides on the Expression of Wee1, Cdc25C-ser-216-p,

CDK1 andCyclin B in NCI-H209 cells. The results of SDS-PAGE are presented in

Figure 4. The results demonstrated that quercetin glucuronides increased WEE1 and Cdc25C-ser-216-p levels, and inhibited cyclin B level, whereas did not affect the CDK1 level. These results also implied that quercetin glucuronides induced cell cycle arrest at G2/M transition.

Quercetin Glucuronides Induced DNA Fragmentation in NCI-H209 Cells. DNA 
DMD 5280

fragmentation was performed in DNA gel electrophoresis. The result indicate that high dose of quercetin glucuronides $(10 \mu \mathrm{M})$ did induced apoptosis because the occurrence of DNA laddering (data not shown). This result was in agreement with the results from flow cytometric assays.

Effects of Quercetin Glucuronides on ROS in NCI-H209 Cells. The change in ROS levels of NCI-H209 cells in response to different concentrations of quercetin glucuronides were studied by staining cells with 2,7-Dichlorodihydrofluorescein diacetate, and then analyzed by flow cytometry. The results showed that ROS levels did not change significantly between the control and the treated cells (data not shown).

Effects of Quercetin Glucuronides on Mitochondrial Membrane Potential. The changes of mitochondrial membrane potential levels of NCI-H209 cells in response to the effect of different concentrations of quercetin glucuronides were studied by staining cells with DiOL6 then analyzed by flow cytometry. The representative profile is showed in Figure 5 and the data are shown in Table 1, which revealed that mitochondrial membrane potential was decreased in NCI-H209 cells after treatment with quercetin glucuronides. This effect was does-dependent. 
DMD 5280

\section{Inhibition of Quercetin Glucuronides-induced Caspase Activation and Apoptosis}

by z-VAD-fmk. These experiments were performed to examine whether caspase-3 activation is involved in the apoptosis triggered by quercetin glucuronides. The results indicate that quercetin glucuronides increased caspase-3 activity and these effects are dose-and time-dependent (Figs. 6A and 6B). NCI-H209 cells had been pretreated with the cell permeable broad-spectrum caspase inhibitor z-VAD-fmk, 3 hours prior to the treatment with quercetin glucuronides. The caspase inhibitor did decrease caspase-3 activity (Fig. 6C). After treatment with quercetin glucuronides and z-VAD-fmk in NCI-H209 cells, inhibition of quercetin glucuronides-mediated caspase-3 activation was accompanied by the marked attenuation of quercetin glucuronides -induced apoptotic cell death (Figs. 6C and 6D). The results revealed that activation of caspase- 3 contributes to quercetin glucuronides-induced apoptosis in NCI-H209 cells.

Poly-(ADP ribose) Monoclonal Antibody Assay for Apoptosis in NCI-H209 Cells. Apoptosis of NCI-H209 cells were also determined by poly-(ADP-ribose) fluorescence staining. When the apoptosis occurs to the cells' DNA, cells might produce poly-(ADP-ribose) polymerase (PARP) for repair of damaged DNA, and the 
DMD 5280

enzyme could be recognized by the antibody. Figure 7 shows PARP positive fluorescence at $0.5,1,2.5,5$, and $10 \mu \mathrm{M}$ of quercetin glucuronides. The results also showed that higher number of cells being stained in response to higher concentrations of quercetin glucuronides.

Effect of Quercetin Glucuronides on the Production of p21 ${ }^{\mathrm{CIP1} / \mathrm{WAF} 1}$, Bak, Bax, Cytochrome c, Bcl-2, and Caspase-3 from NCI-H209 Cells. Total proteins were prepared and followed by Western blotting, and the results from SDS-PAGE are presented in Figure 8. The results demonstrated that quercetin glucuronides increased $\mathrm{p} 21^{\mathrm{CIP} 1 / \mathrm{WAF} 1}, \mathrm{Bak}, \mathrm{Bax}$, cytochrome $\mathrm{c}$, and caspase- 3 levels, but decreased Bcl-2 level. These findings suggest that quercetin glucuronides induced apoptosis through these molecular events.

\section{DISCUSSION}

In the past years, the strategy for killing cancer cells through the induction of apoptosis has been extensively studied (Norbury and Zhivotovsky, 2004; Ferreira et al, 2002). In general, the initiation of cellular apoptosis is through two distinct pathways: one is the extrinsic pathway involved the death receptor signaling and the other is the intrinsic pathway involved the mitochondrial cascades (Kroemer and Reed, 
DMD 5280

2000; Green and Amarante-Mendes, 1998; Henry-Mowatt et al, 2004). Activation of either one of the pathway by cleavage the procaspase- 8 or -9 will in turn result in downstream activation of caspase-3, caspase-activated DNase, and finally lead to DNA fragmentation (Norbury and Zhivotovsky, 2004; Ferreira et al, 2002). Activation of caspase-3 is often considered as the point-of-no-return in the apoptotic signaling cascade (Green and Amarante-Mendes, 1998).

In this study, we demonstrated that the possible roles of quercetin glucuronides on the human lung cancer NCI-H209 cells were (1) to decrease the percentage of viable cells in a dose- and time- dependent effect, (2) to arrest the cell cycle at the G2/M transition via cyclin B, WEE1, Cdc25C-ser-216-p, and p21 checkpoints, (3) to induce apoptosis via promoting the caspases-9 and -3 activities, and to block apoptosis by co-treatment with the caspase inhibitor z-VAD-fmk. Our results provide evidence that quercetin glucuronides-induced apoptosis results from intrinsic pathway involved the mitochondrial cascades in NCI-H209 cells.

Although DNA damage due to reactive oxygen species (ROS) is involved in apoptosis, levels of hydrogen peroxide were not affected and the percentage of apoptosis was not influenced by cotreatment with catalase (the scavenger of $\mathrm{H}_{2} \mathrm{O}_{2}$ ) in NCI-H209 cells. This indicates that quercetin glucuronides may have antioxidant activity and its induction of apoptosis is not dependent on the presence of $\mathrm{H}_{2} \mathrm{O}_{2}$, 
DMD 5280

which is in agreement with the observation by Park et al (2003).

It has been suggested that the intranuclear mechanisms after DNA damage are highly conserved in initiating apoptosis, cell cycle arrest or DNA repair (Ferreira et al, 2002) The G2/M phase checkpoint plays a key role in providing time for DNA repair, and it provide an alternative pathway to apoptosis to remove irreparably damaged cells (Kroemer and Reed, 2000; Castedo et al, 2002). We demonstrated that quercetin glucuronides induced $\mathrm{G} 2 / \mathrm{M}$ arrest (at $12 \mathrm{hr}$ ) before the onset of apoptosis (at $24 \mathrm{~h}$ or later) from cell cycle analysis (Figs. 2A and 2B). The Cdk1/cyclin B complex has been well known as the regulators governing the $\mathrm{G} 2$ to $\mathrm{M}$ progression or inducing apoptosis (Castedo et al, 2002). Wee1, Cdc25C, and p21 ${ }^{\mathrm{CIP} 1 / \mathrm{WAF} 1}$ can be G2/M checkpoints in human cells (Pines and Hunter, 1991; McGowan and Russel, 1993; Jackson et al, 2000). Wee1 delays mitosis, whereas Cdc25C advances mitosis (Russel and Nuse, 1986; Russel and Nuse, 1987; Lew and Kornbluth, 1996); moreover, G2 DNA damage checkpoint simultaneously signals via both up-regulation of Wee1p (phosphorylation of Wee1) and down-regulation of Cdc25p (phosphorylation of Cdc25), thus providing a double-lock mechanism to ensure cell cycle arrest and genomic stability (Raleigh, et al, 2000). The $\mathrm{p} 21^{\mathrm{CIP} 1 / \mathrm{WAF} 1}$ (an inhibitor of $\mathrm{Cdk}$ ) binds to and inactivates most Cdk-cyclin complexes and induces cell cycle arrest either at G0/G1 or G2/M transition (Dulic et al, 1998). Cdc25C is a 
DMD 5280

dual-specific protein phosphatase that controls the entry into mitosis by dephosphorylating the protein kinase Cdc2; however, Cdc25C-ser-216-p creates a binding site for 14-3-3 protein and inhibits the function of Cdc25C phosphatase (Peng et al, 1997; Sanchez et al, 1997). G2 arrest is initiated via phosphorylation of Cdc25C on serine-216 by Chk1 or Chk2, and the maintenance of G2 arrest is highly p53 dependent and involves its transcriptional targets p21 (Cdk inhibitor) and protein 14-3-3 (the adaptor) (Ohi and Gould, 1999; Takizawa and Morgan, 2000; Taylor and Stark, 2001). Charrier-Savournin has recently demonstrated that p21 inhibits cyclin B1-Cdk1 activation by binding to and sequestering them in the nucleus, implying that p21 could efficiently block initiation of early mitotic events (Charrier-Savournin et al, 2004). Our results showed that quercetin glucuronides-induced G2/M arrest is closely related to the increase of Wee1 and Cdc25C-ser-216-p levels, and to the decrease of cyclin B level (Figs. 3C and 3D). Therefore, signals elicited by DNA damage in S and G2 phases prevent mitotic entry by inhibiting both activation (via inactivation of Cdc25) and import of cyclin B1/Cdk1 in quercetin glucuronidestreated NCI-H209 cells.

Recently, quercetin-induced growth inhibition and apoptosis has been demonstrated in human lung cancer cells (Nguyen et al, 2004; Kuo et al, 2004). Nguyen et al found that alterations of Bcl-2 family proteins, inactivation of Akt-1 and activation of 
DMD 5280

MEK-ERK all play a role during quercetin-induced apoptosis in A549 lung epidermoid cancer cells (Nguyen et al, 2004). Kuo et al found that survivin reduces the cell growth inhibition and apoptosis, and p53 elevates the p21 level, which may delay cell death in the quercetin-treated A549 (p53-contained) and H1299 (p53-null) human non-small cell lung cancer cell lines (Kuo et al, 2004). On the other hand, we demonstrated loss of mitochondria membrane potential and release of mitochondrial cytochrome c to cytosol in quercetin glucuronides-treated cells. We also showed the up-regulation of Bax and Bak and down-regulation of Bcl-2, and increased levels of caspase-9, and caspase-3 accompanied by cleavage of PARP in NCI-H209 cells. These data support that quercetin glucuronides induce apoptosis in human small-cell lung carcinoma NCI-H209 cells, and the molecular mechanisms of apoptosis involved in the mitochondria-dependent pathway. Furthermore, z-VAD-fmk, a caspase inhibitor, inhibited the caspase-3 activity and totally blocked the apoptotic effect, indicating that quercetin glucuronides-induced apoptosis is caspase-3 dependent.

The release of cytochrome $c$ from mitochondria to cytosol, related to loss of mitochondrial membrane potential, is the central gate in turning on/off apoptosis, and is closely regulated by the $\mathrm{Bcl}-2$ family proteins. The proapoptotic members of the Bcl-2 family proteins include Bax, Bak, Bad, Mtd, Diva, and BH3-only proteins, and the antiapoptotic members include Bcl-2, Bcl-X $\mathrm{L}$, Bcl-w, Mcl-1, Bfl-1 and Boo/Diva, 
DMD 5280

and a specific class of inhibitors of apoptosis proteins (IAPs) including c-IAP1, c-IAP2, XIAP, survivin, and others (Norbury and Zhivotovsky, 2004). Bax and Bak, normally located in the cytosol, are activated, and then translocated to the mitochondria and permeabilize the outer mitochondrial membrane facilitating release of cytochrome c from mitochondria to cytosol in response to apoptotic stimuli (45). Cytochrome c subsequently trigger the formation of apoptosome consisting of procaspase-9, Apaf-1 and cytochrome $\mathrm{c}$ in the presence of dATP, and turning on the executioner caspases-9 and -3 (Li et al, 1997; Green and Reed, 1998). Bax and Bak also act on the endoplasmic reticulum (ER), and their role on ER may be the release of $\mathrm{Ca}^{2+}$ ions and the activation of caspase-12, which subsequently activate the caspase-3 cascade ( $\mathrm{Li}$ et al, 1997; Wei et al, 2001; Scorrano et al, 2003; Zong et al, 2003). Therefore, it is of great interest to further clarify the cross-talk between mitochondria and ER by quercetin glucuronides in cancer cells.

In conclusion, we demonstrated that quercetin glucuronides inhibited cell proliferation through cell cycle arrest at $\mathrm{G} 2 / \mathrm{M}$ phase and induction of mitochondria-mediated apoptosis in human lung cancer cells (NCI-H209). Delineation of the biological effects of specific major quercetin metabolites on chemotherapeutic potential or chemoprevention of human cancers warrants further investigation. 
DMD 5280

\section{REFERENCES}

Castedo M, Perfettini JL, Roumier T and Kroemer G (2002) Cyclin-dependent kinase-1: linking apoptosis to cell cycle and mitotic catastrophe. Cell Death and Differentiation 9;1287-1293.

Charrier-Savournin FB, Chateau MT, Gire V, Sedivy J, Piette J and Dulic V (2004) p21-Mediated nuclear retention of cyclin B1-Cdk1 in response to genotoxic stress. Mol Biol Cell 2004:15:3965-3976.

Cheong E, Ivory K, Doleman J, Parker ML, Rhodes M and Johnson IT (2004) Synthetic and naturally occurring COX-2 inhibitors suppress proliferation in a human oesophageal adenocarcinoma cell line (OE33) by inducing apoptosis and cell cycle arrest. Carcinogenesis 25:1945-1952.

Chua YJ, Steer C and Yip D (2004) Recent advances in management of small-cell lung cancer. Cancer Treat Rev 30:521-543.

Chung JG (1999) Effects of the butylated hydroxyanisole and butylated hydroxytoluene on the acetylation of 2-aminofluorene and DNA-2-aminofluorene adducts in the rat. Toxicol Sci 51:202-210.

Choi JA, Kim JY, Lee JY, Kang CM, Kwon HJ, Yoo YD, Kim TW, Lee YS and Lee SJ (2001) Induction of cell cycle arrest and apoptosis in human breast cancer cells by quercetin. Int J Oncol 19:837-844.

Day AJ, Bao Y, Morgan MR and Williamson G. (2000) Conjugation position of quercetin glucuronides and effect on biological activity. Free Radic Biol Med 29, 1234-1243.

Dulic V, Stein GH, Far DF and Reed SI (1998) Nuclear accumulation of p21 ${ }^{\mathrm{Cip} 1}$ at the onset of mitosis: a role at the G2/M-phase transition. Mol Cell Biol 18, 546-557.

Ferreira CG, Epping M, Kruyt FA and Giaccone G (2002) Apoptosis: target of cancer 
DMD 5280

therapy. Clin Cancer Res 8, 2024-2034.

Green, C.R., Reed, J.C., 1998. Mitochondria and apoptosis. Science 281, 1309-1312.

Green DR, and Amarante-Mendes GP (1998) The point-of-no-return: mitochondria, caspases, and the commitment to cell death. Results Probl Cell Differ 24, 45-61.

Greenlee RT, Murray T, Bolden S and Wingo PA (2000) Cancer statistics, 2000. CA Cancer J Clin 50, 7-30.

Henry-Mowatt J, Dive C, Martinou JC and James D (2004) Role of mitochondrial membrane permeabilization in apoptosis and cancer. Oncogene 23, 2850-2860.

Hertog MGL, Hollman PCH, Van Leeuwen SD, Mengelers MJB and Katan MB (1993) Intake of potentially anticarcinogenic flavonoids and their determinants in adults in the Netherlands. Nutr Cancer 20, 21-9.

Innocente SA, Abrahamson JL, Cogswell JP and Lee JM (1999) p53 regulates a G2 checkpoint through cyclin B1. Proc Natl Acad Sci U S A 96, 2147-2152.

Jackson JR, Gilmartin A, Imburgia C, Winkler JD, Marshall La and Roshak A (2000) An indolocarbazole inhibitor of human checkpoint kinase (Chk1) abrogates cell cycle arrest caused by DNA damage. Cancer Res 60, 566-572.

Jakubowicz-gil J, Rzymowska J and Gawron A (2002) Quercetin, apoptosis, heat shock. Biochem Pharmacol 64, 1591-1595.

Kalbacova M, Vrbacky M, Drahota Z and Melkova Z (2003) omparison of the effect of mitochondrial inhibitors on mitochondrial membrane potential in two different cell lines using flow cytometry and spectrofluorometry. Cytometry 52A, 110-116.Kaneuchi M, Sasaki M, Tanaka Y, Sakuragi N, Fujimoto S and Dahiya R (2003) Quercetin regulates growth of Ishikawa cells through the suppression of EGF and cyclin D1. Int J Oncol 22, 159-164.

Kuo PC, Liu HF and Chao JL (2004) Survivin and p53 modulate quercetin-induced cell growth inhibition and apoptosis in the human lung carcinoma cells. J Biol 
DMD 5280

Chem 279, 55875-55885.

Kuo HM, Ho HJ, Chao PD and Chung JG (2002) Quercetin glucuronides inhibited 2-aminofluorene acetylation in human acute myeloid HL-60 leukemia cells. Phytomedicine 9, 625-631.

Kroemer G and Reed JC (2000) Mitochondrial control of cell death. Nat Med 6, 513-519.

Lee YM, Wu TH, Chen SF and Chung JG (2003) Effect of 5-methoxypsoralen (5-MOP) on cell apoptosis and cell cycle in human hepatocellular carcinoma cell line. Toxicol In Vitro 17, 279-287.

Lew DJ and Kornbluth S (1996) Regulatory roles of cyclin dependent kinase phosphorylation in cell cycle control. Curr Opin Cell Biol 8, 795-804.

Li P, Nijhawan D, Budihardjo I, Srinivasula SM, Ahmed M, Alnemri ES and Wang X (1997) Cytochrome c and dATP-dependent formation of Apaf-1/caspase-9 complex initiates as apoptotic protease cascade. Cell 91, 479-489.

Lu HF, Sue CC, Yu CS, Chen SC, Chen GW and Chung JG (2004) Diallyl disulfide (DADS) induced apoptosis undergo caspase-3 activity in human bladder cancer T24 cells. Food Chem Toxicol 42, 1543-1552.

Manach C, Scalbert A, Morand C, Remesy C and Jimenez L (2004) Polyphenols: food sources and bioavailability Am J Clin Nutr 79, 727-747.

McGowan CH and Russell P (1993) Human Weel kinase inhibits cell division by phosphorylating p34cdc2 exclusively on Tyr15. EMBO J 12, 75-85.

Middleton E Jr, Kandaswami C and Theoharides TC (2000) The effects of plant flavonoids on mammalian cells: implications for inflammation, heart disease, and cancer. Pharmacol Rev 52, 673-751.

Norbury CJ and Zhivotovsky B (2004) DNA damage-induced apoptosis. Oncogene 23, 2797-2808. 
DMD 5280

Nguyen TT, Tran E, Nguyen TH, Do PT, Huynh TH and Huynh H (2004) The role of activated MEK-ERK pathway in quercetin-induced growth inhibition and apoptosis in A549 lung cancer cells. Carcinogenesis 25, 647-659.

Ohi R and Gould KL (1999) Regulating the onset of mitosis. Curr Opin Cell Biol 11, 267-273.

Ong CS, Tran E, Nguyen TT, Ong CK, Lee SK, Lee JJ, Ng CP, Leong C and Huynh H (2004) Quercetin-induced growth inhibition and cell death in naspharyngeal carcinoma cells are associated with increase in Bad and hypophosphorylated retinoblastoma expressions. Oncol Rep 11, 727-733.

Orzechowski A, Grzelkowska K, Zimowska W, Skierski J, Ploszaj T, Bachanek K, Motyl T, Karlik W and Filipecki M (2000) Induction of apoptosis and NF- $\kappa$ B by quercetin in growing murine L1210 lymphocytic leukaemic cells potentiated by TNF-alpha. Reprod Nutr Dev 40, 441-465.

Ormerod MG (1990) Flow Cytometry: A Practical Approach, pp 69-81, Oxford University Press, New York.

Park C, So H S, Shin C H, Baek SH, Moon BS, Shin SH, Lee HS, Lee DW and Park R (2003) Quercetin protects the hydrogen peroxide-induced apoptosis via inhibition of mitochondrial dysfunction in H9c2 cardiomyoblast cells. Biochem Pharmacol 66, 1287-1295.

Peng CY, Graves PR, Thoma RS, Wu Z, Shaw AS and Piwnica-Worms H (1997) Mitotic and G2 checkpoint control: regulation of 14-3-3 protein binding by phosphorylation of Cdc25C on serine-216. Science 277, 1501-1505.

Pettit GR, Hoard MS, Doubek DL, Schmidt JM, Pettit RK, Tackett LP and Chapuis JC (1996) Antineoplastic agents 338: The cancer cell growth inhibitory. Constituents of Terminnalia arjuna. J Ethnopharmacol 53, 57-63.

Pines J and Hunter T (1991) Human cyclin A and B1 are differentially located in the 
DMD 5280

cell and undergo cell cycle-dependent nuclear transport. J Cell Biol 115, 1-17.

Raleigh JM and O'Connell MJ (2000) The G2 DNA damage checkpoint targets both Wee1 and Cdc25. J Cell Sci 113 ( Pt 10):1727-36.

Russel P and Nuse P (1986) cdc25+ functions as an inducer in the mitotic control of fission yeast. Cell 45, 145-153.

Russel P and Nuse P (1987) Negative regulation of mitosis by Wee1+, a gene encoding a protein kinase homolog. Cell 1987;49:559-567.

Sanchez Y, Wong C, Thoma RS, Richman R, Wu Z, Piwnica-Worms H and Elledge SJ (1997) Conservation of the Chk1 checkpoint pathway in mammals: linkage of DNA damage to Cdk regulation through Cdc25. Science 277, 1497-1501.

Scorrano L, Oakes SA, Opferman JT, Cheng EH, Sorcinelli MD, Pozzan T and Korsmeyer SJ (2003) BAX and BAK regulation of endoplasmic reticulum $\mathrm{Ca}^{2+}: \mathrm{A}$ control point for apoptosis. Science 300, 135-139.

Takizawa GT and Morgan DO (2000) Control of mitosis by changes in the subcellular location of cyclin-B1-Cdk1 and Cdc25C. Curr Opin Cell Biol 12, 658-665.

Taylor WR and Stark GR (2001) Regulation of the G2/M transition by p53. Oncogene 20, 1803-1815.

Wei MC, Zong WX, Cheng EH, Lindsten T, Panoutsakopoulou V, Ross AJ, Roth KA, MacGregor GR, Thompson CB and Korsmeyer SJ (2001) Proapoptotic BAX and BAK: A requisite gateway to mitochondrial dysfunction and death. Science 292, 727-730.

Wittig J, Herderich M, Graefe EU and Veit M (2001) Identification of quercetin glucuronides in human plasma by high-performance liquid chromatography-tandem mass spectrometry. J Chromatogr B 753, 237-243.

Yoshida M, Sakai T, Hosokawa N, Marui N, Matsumoto K, Fujioka A, Nishino H and Aoike A (1990) The effect of quercetin on cell cycle progression and growth of 
DMD 5280

human gastric cancer cells. FEBS Lett 260, 10-13.

Zong WX, Li C, Hatzuvassiliou G, Lindsten T, Yu QC, Yuan J and Thompson CB (2003) Bax and Bak can localize to the endoplasmic reticulum to initiate apoptosis. Journal of Cell Biology 162, 59-69. 
DMD 5280

Footnotes: This study was supported by grants CMU-M-17 (2003) from the Biomedical Research Section of China Medical University, Taichung, Taiwan.

\section{Corresponding author: Jing-Gung Chung, Ph.D.;}

School of Life Science, China Medical University, No 91, Hsueh-Shih Road, Taichung 404, Taiwan, Republic of China

Tel: 886-4-2205-3366-8501, Fax: 886-4- 2205-3764,

E-mail: jgchung@mail.cmu.edu.tw 
DMD 5280

\section{LEGENDS FOR FIGURES}

Figure 1. Structure of quercetin and quercetin glucuronides.

Figure 2. The percentage of the viable NCI-H209 cells after quercetin glucuronides treatment with 24 hours incubation. NCI-H209 cells $\left(2 \times 10^{5}\right.$ cells/well; 12 well plates) were plated in RPMI 1640 medium $+10 \%$ FBS with different concentrations of quercetin glucuronides for 24 hours (panel A) or $5 \mu \mathrm{M}$ quercetin glucuronides for 6 , 12, 24 and 48 hours (panel B). Then cells were collected by centrifugation and the viable cells were determined by trypan blue exclusion and flow cytometry as described in Materials and Methods. Each point is mean \pm S.D. of three experiments. $* \mathrm{P}<0.05$

Figure 3. Flow cytometric analysis of the effects of quercetin glucuronides on the cell cycle and sub-G1 group in NCI-H209 cells. The NCI-H209 cells were exposed to various concentrations of quercetin glucuronides for 48 hours, and the cells were harvested and analyzed for cell cycle (panel 3A: representative profiles; panel 3B: the percent of cells in phase) and sub-G1 group (panel 3C: the percent of cells in apoptosis) were analyzed by flow cytometry as described in Materials and Methods. Data represents mean \pm S.D. of the results obtained from three experiments. $* \mathrm{P}<0.05$

Figure 4. Representative Western blot showing changes on the levels of Wee1, Cdc25C-ser-216-p, CDK1 and cyclin B in NCI-H209 cells after exposure to quercetin glucuronides. NCI-H209 cells $\left(5 \times 10^{6} / \mathrm{ml}\right)$ were treated with $0,0.5,1,2.5,5$ and 10 $\mu \mathrm{M}$ quercetin glucuronides for 24 hours, then cytosolic fraction and total protein were prepared and determined as described in Materials and Methods. Then, we 
DMD 5280

measured the levels of Wee1, Cdc25C-ser-216-p, CDK1 and cyclin B expressions by Western blotting.

Figure 5. The effect of quercetin glucuronides on mitochondrial membrane potential in human lung cancer NCI-H209 cells. The NCI-H209 cells $\left(5 \times 10^{5}\right.$ cells $/ \mathrm{ml}$ ) were treated with various concentrations of quercetin glucuronides. The representative profiles are control and cells that were treated with 50 and $100 \mu \mathrm{M}$ quercetin glucuronides. The percentage of cells that were stained by DiOL6 dye, and the stained cells were determined by flow cytometry as described in the Materials and Methods section.

Figure 6. Effects of quercetin glucuronides on caspase-3 and apoptosis on human lung cancer NCI-H209 cells treated with and/or without the caspase inhibitor z-VAD-fmk. The NCI-H209 cells were incubated with various concentrations of quercetin glucuronides (panel A) for various time periods (panel B) and/or with or without z-VAD-fmk treatment (panel C) for caspase-3 activity and apoptosis determination as described in Materials and Methods. Data represents mean \pm S.D. of three experiments. $* \mathrm{P}<0.05$

Figure 7. The figure shows the effects of quercetin glucuronides on apoptosis of NCI-H209 cells. The NCI-H209 cells were incubated with variable concentrations of quercetin glucuronides for 48 hours, and the cells were harvested and stained by anti-PARP antibody and photographed for apoptosis as described in Materials and Methods. The figure shows PARP positive fluorescence at $0,5,1,2.5,5$, and $10 \mu \mathrm{M}$ of quercetin glucuronides. Cells in green color represented the cells undergoing apoptosis. 
DMD 5280

Figure 8. Representative Western blot showing changes in the levels of p21 ${ }^{\mathrm{CIP} 1 / \mathrm{WAF} 1}$, Bak, Bax, Bcl-2, cytochrome c, and caspase-3 in NCI-H209 cells after exposure to quercetin glucuronides. NCI-H209 cells $\left(5 \times 10^{6} / \mathrm{ml}\right)$ were treated with $0,0.5,1,2.5$, 5 and $10 \mu \mathrm{M}$ quercetin glucuronides for 24 hours then total proteins were prepared and determined as described in Materials and Methods. Then followed by evaluation of the levels of $\mathrm{p} 21^{\mathrm{CIP1} / \mathrm{WAF} 1}$, Bak, Bax, cytochrome $\mathrm{c}, \mathrm{Bcl}-2$, caspase-3 expressions were estimated by Western blotting as described in Materials and Methods. 
Table 1. Flow cytometric analysis of mitochondrial membrane potential in human lung cancer NCI-H209 cells with or without treatment with quercetin glucuronides for 24 hours.

\begin{tabular}{ll}
\hline Quercetin glucuronides $(\mu \mathrm{M})$ & Percentage of cells stained by $\mathrm{DiOL}_{6}$ \\
\hline 0 (control) & $96.1 \pm 9.2$ \\
0.5 & $88.2 \pm 8.1$ \\
1 & $68.7 \pm 7.1$ \\
2.5 & $44.6 \pm 5.4^{*}$ \\
5 & $29.6 \pm 3.8^{*}$ \\
10 & $12.8 \pm 1.9^{*}$ \\
\hline
\end{tabular}

Values are mean \pm S.D. $n=3$. The NCI-H209 cells $(5 \times 105$ cells $/ \mathrm{ml})$ were treated with various concentrations of quercetin glucuronides. The zero concentration was defined as control. The percentage of cells that were stained by $\mathrm{DiOL}_{6}$ dye, and the stained cells were determined by flow cytometry as described in the Materials and Methods section.

*Difference is significant between quercetin glucuronides-treated and control, $\mathrm{p}<0.05$. 
Fig. 1

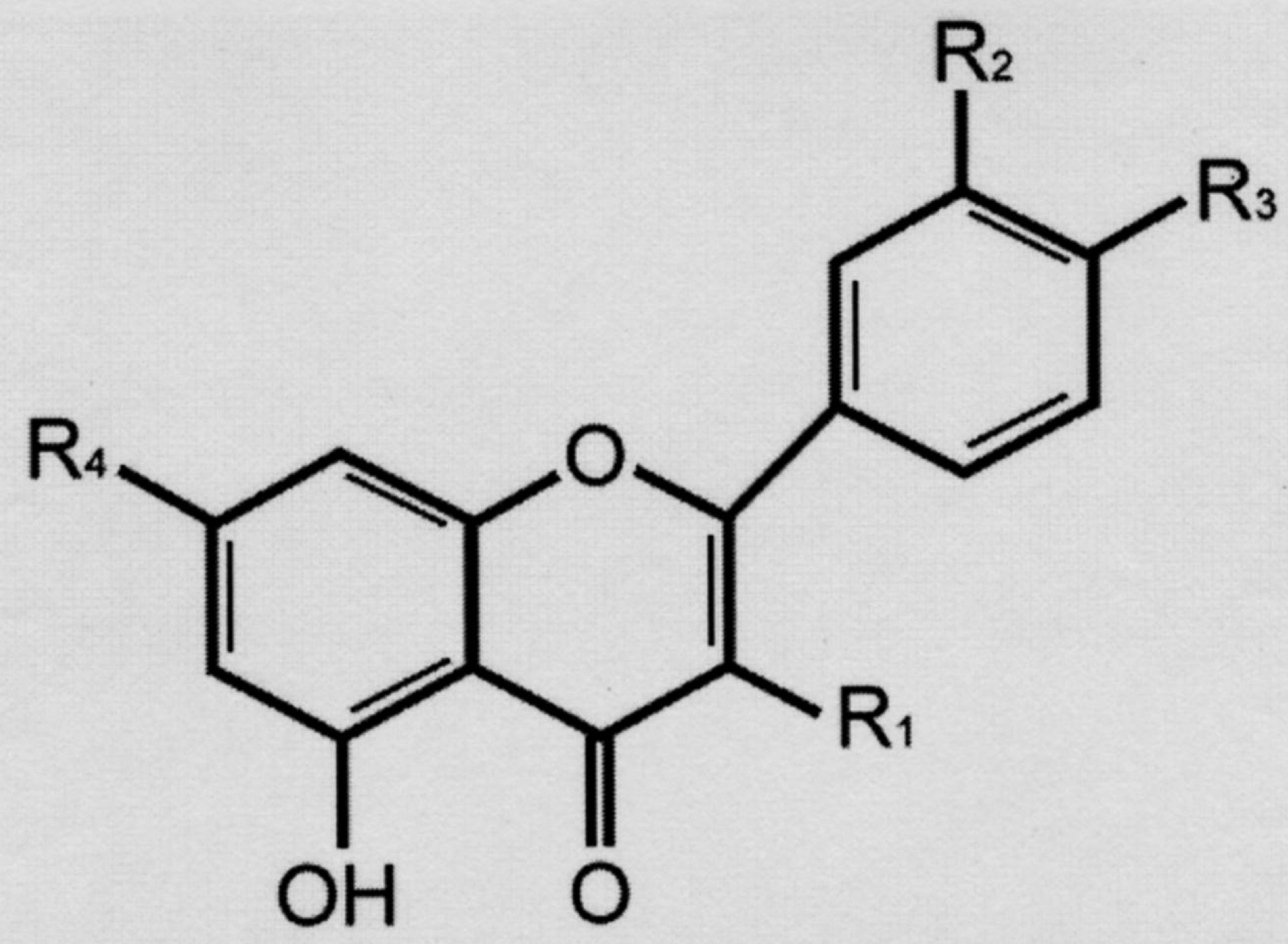

\begin{tabular}{|l|l|l|l|l|}
\hline & R1 & R2 & R3 & R4 \\
\hline Q & OH & OH & OH & OH \\
\hline Q-7-G & OH & OH & OH & G \\
\hline Q-3-G & G & OH & OH & OH \\
\hline Q-4'-G & OH & OH & G & OH \\
\hline
\end{tabular}

Q: quercetin; G: O-glucuronide 
Fig. 2A

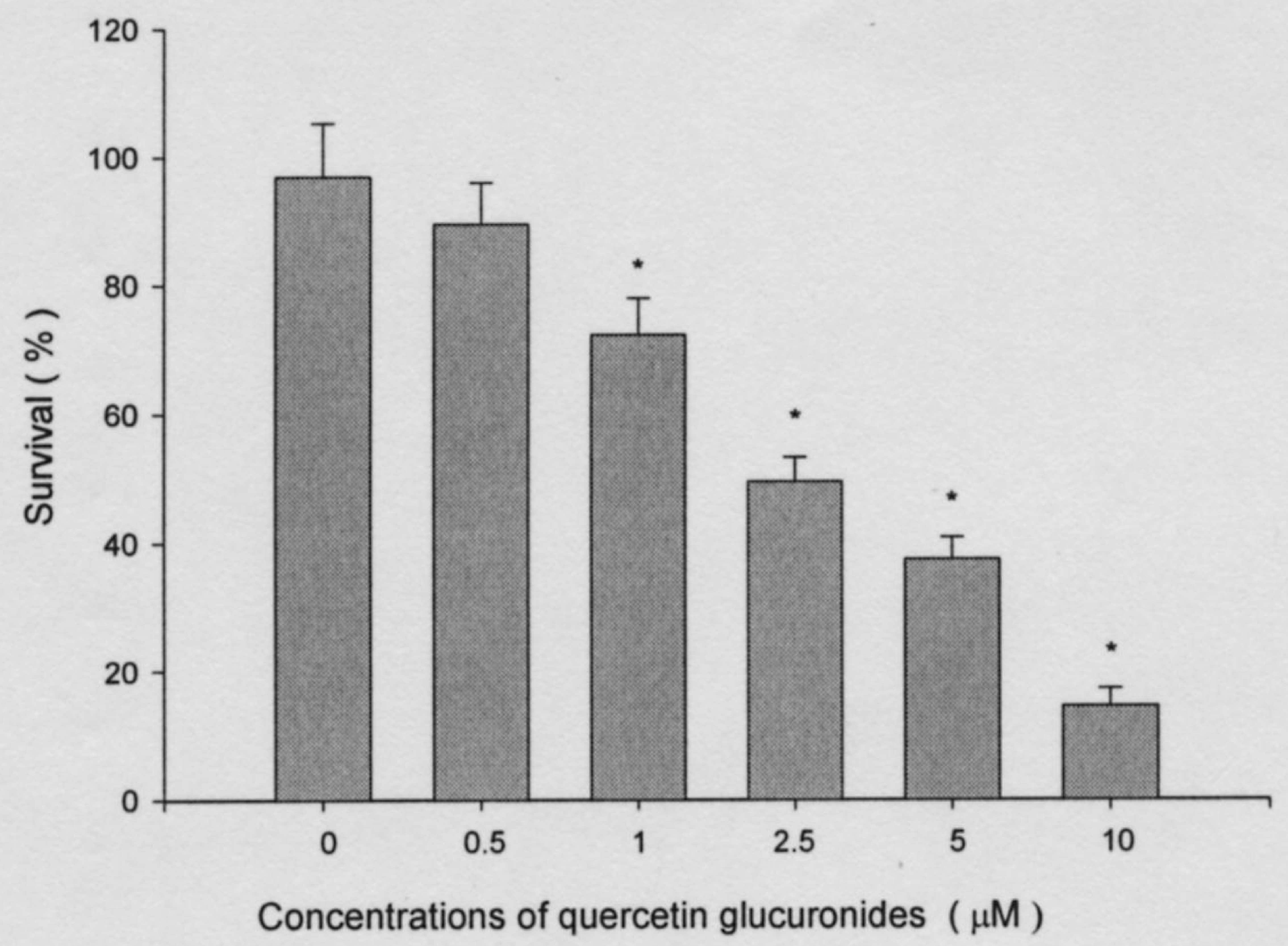

Fig. 2B

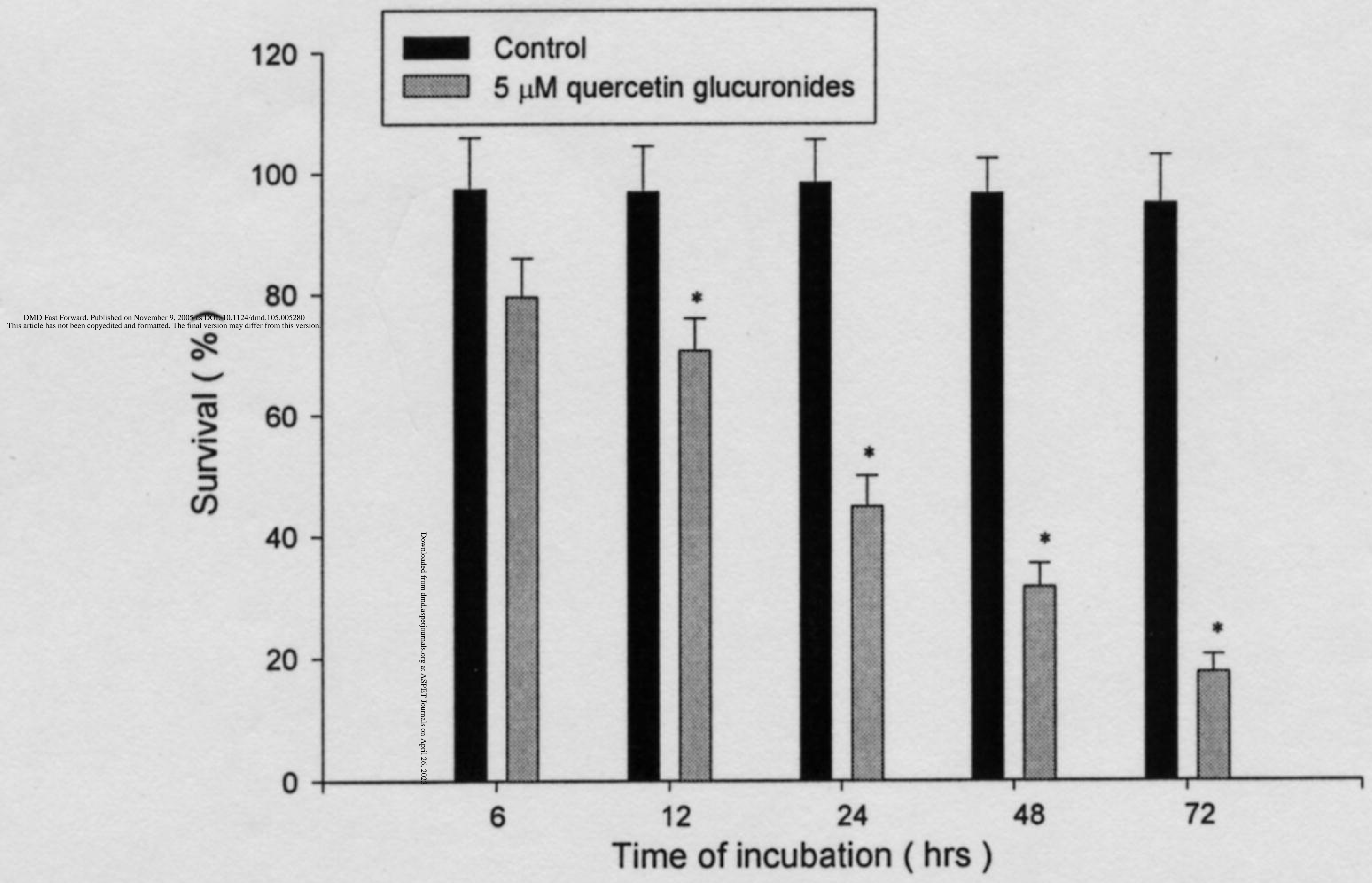


Fig. 3A

\section{control}

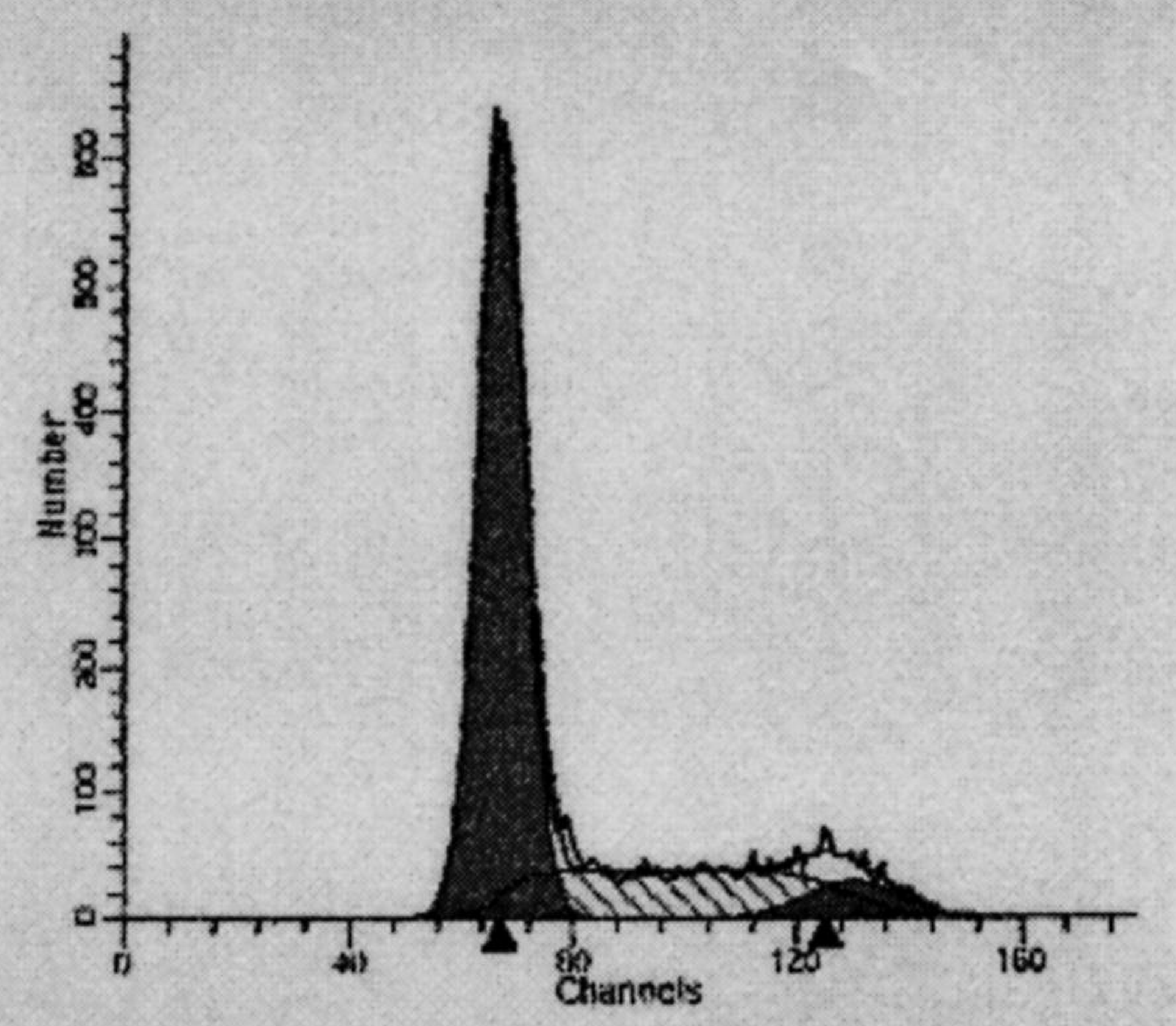

$10 \mu \mathrm{M}$ quercetin glucuronides

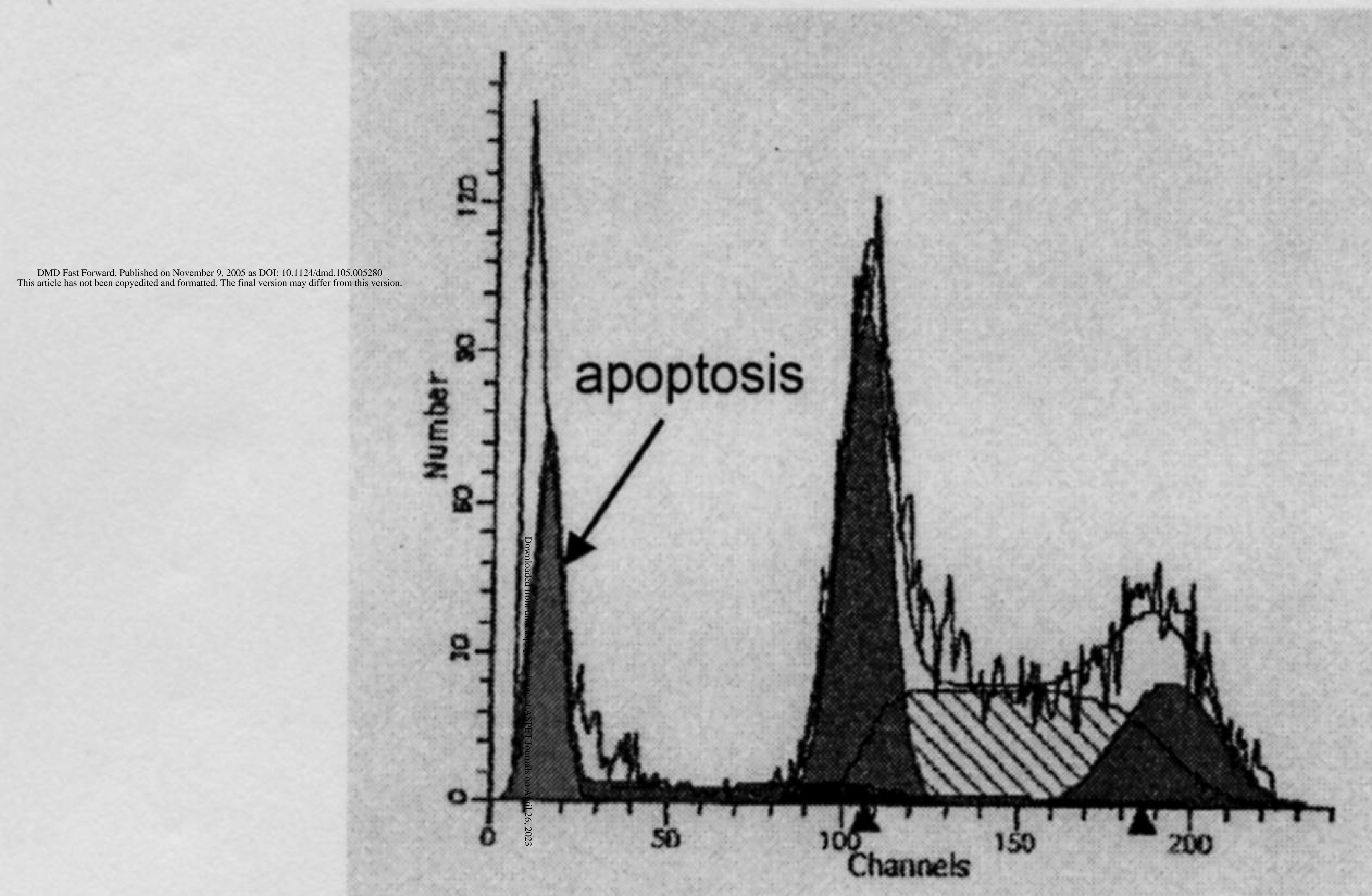


Fig. 3B

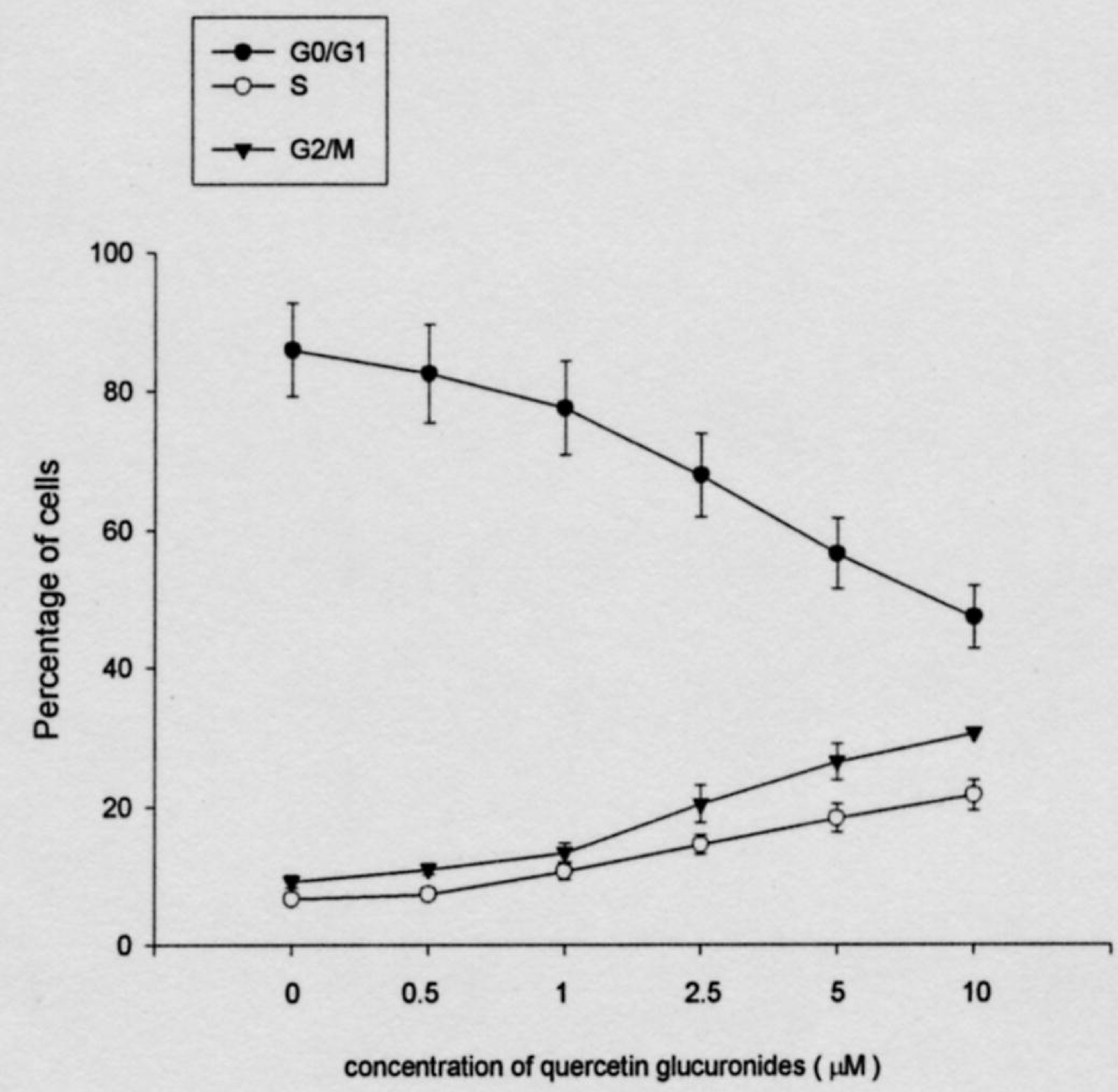

Fig. 3C

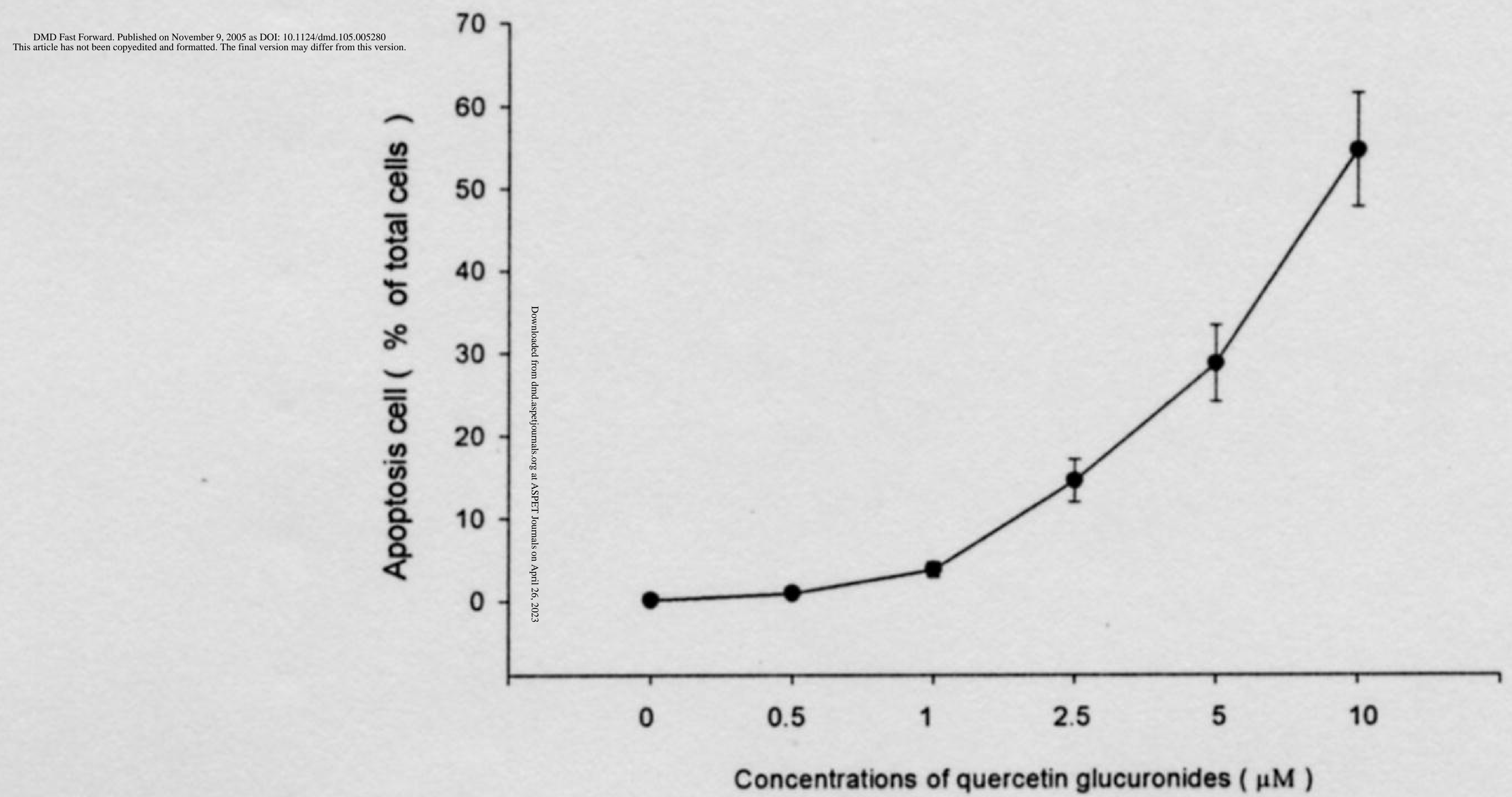


Fig. 4A

\section{Quercetin glucuronides $(\mu \mathrm{M})$}

$$
\begin{array}{llllll}
0 & 0.5 & 1 & 2.5 & 5 & 10
\end{array}
$$

Wee1

$$
\beta \text { - actin }
$$

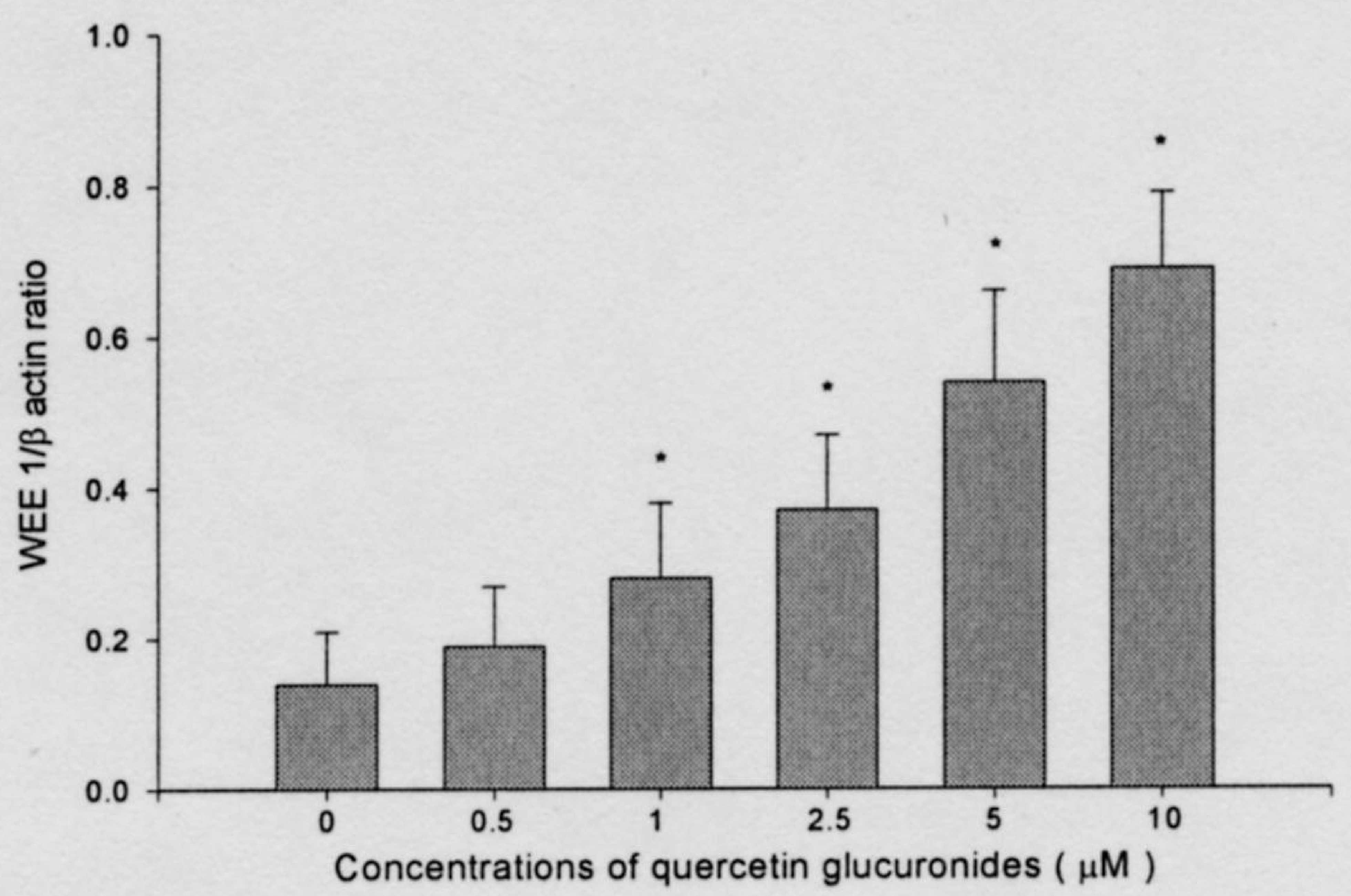


Fig. 4B

\section{Quercetin glucuronides $(\mu \mathrm{M})$}

\section{$\begin{array}{llllll}0 & 0.5 & 1 & 2.5 & 5 & 10\end{array}$}

\section{cdc25C-ser-216-p}

$$
\beta \text { - actin }
$$

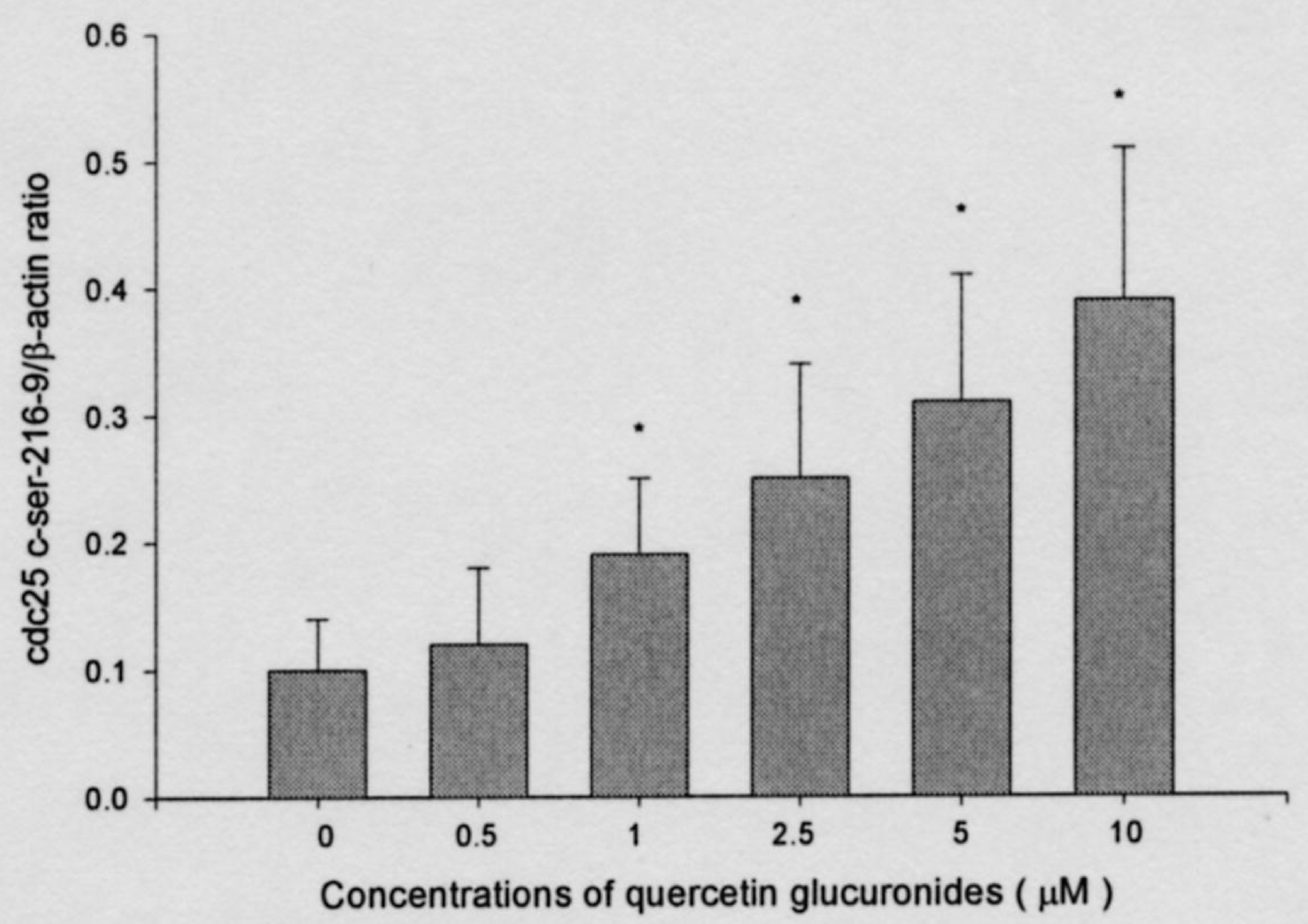


Fig. 4C

\section{Quercetin glucuronides $(\mu \mathrm{M})$ \\ $\begin{array}{llllll}0 & 0.5 & 1 & 2.5 & 5 & 10\end{array}$}

\section{CDK1}

$\beta$ - actin

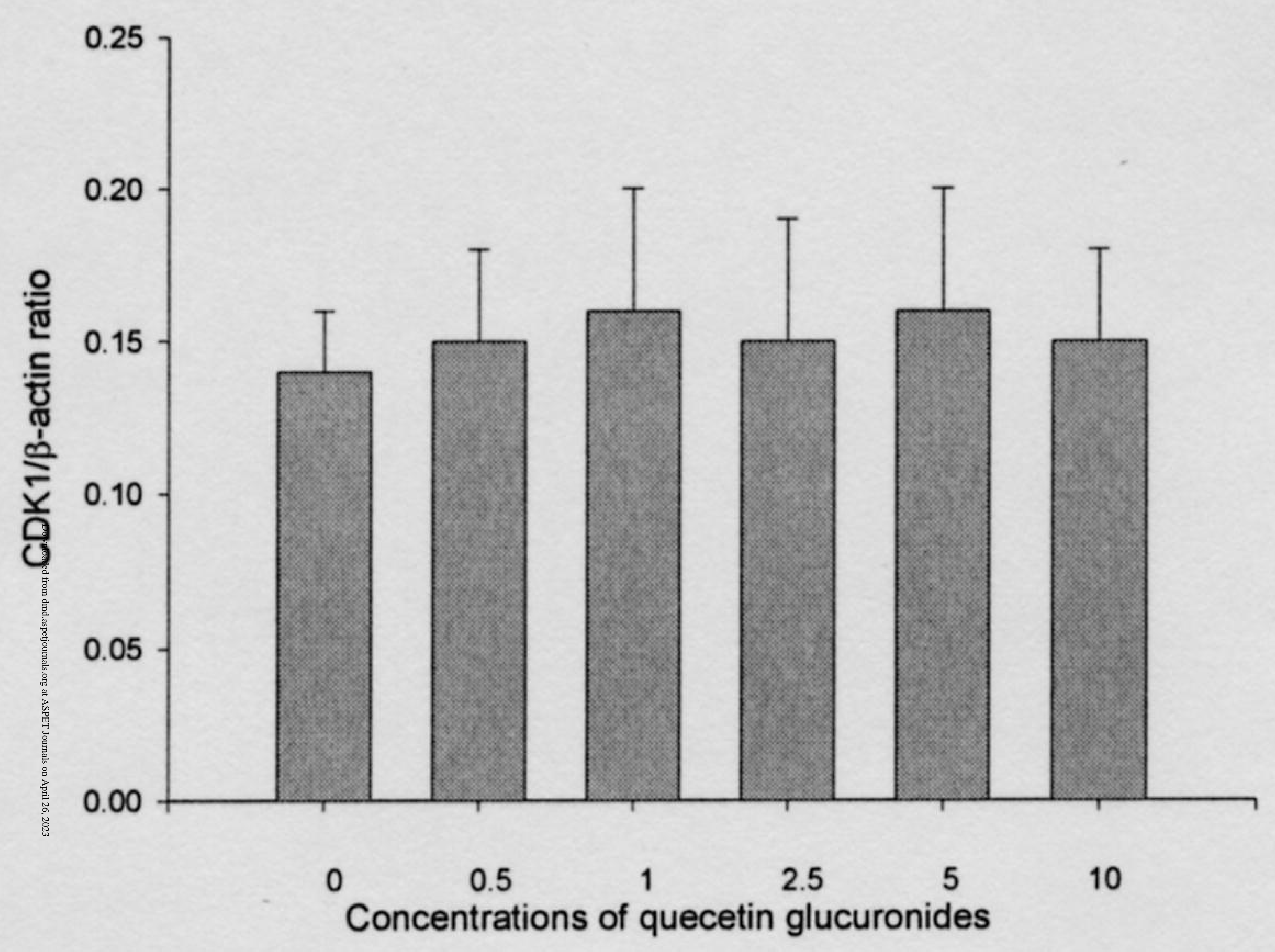


Fig. 4D

\section{Quercetin glucuronides $(\mu \mathrm{M})$ \\ $\begin{array}{llllll}0 & 0.5 & 1 & 2.5 & 5 & 10\end{array}$}

\section{Cyclin B}

$\beta$ - actin

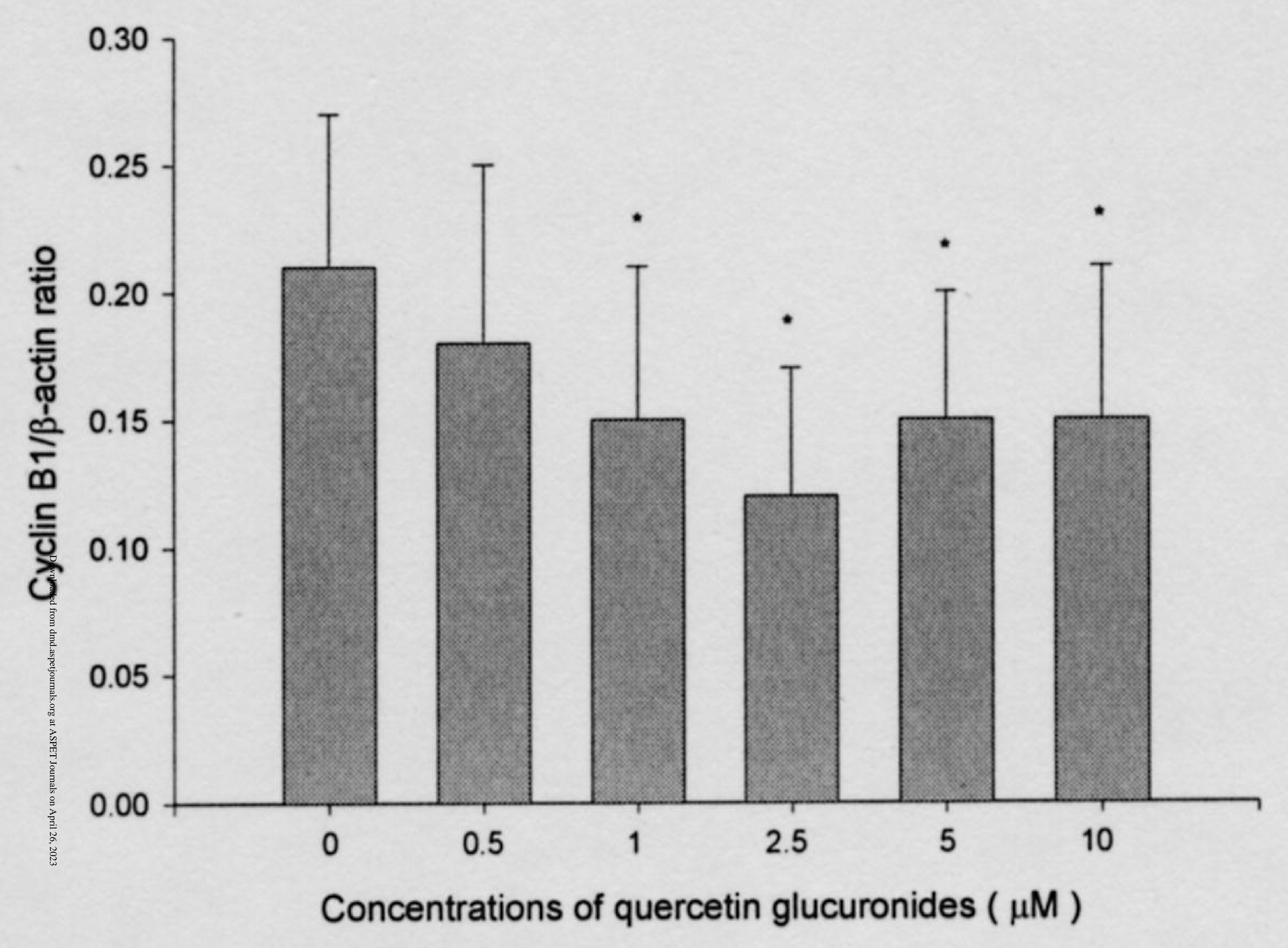


Fig. 5

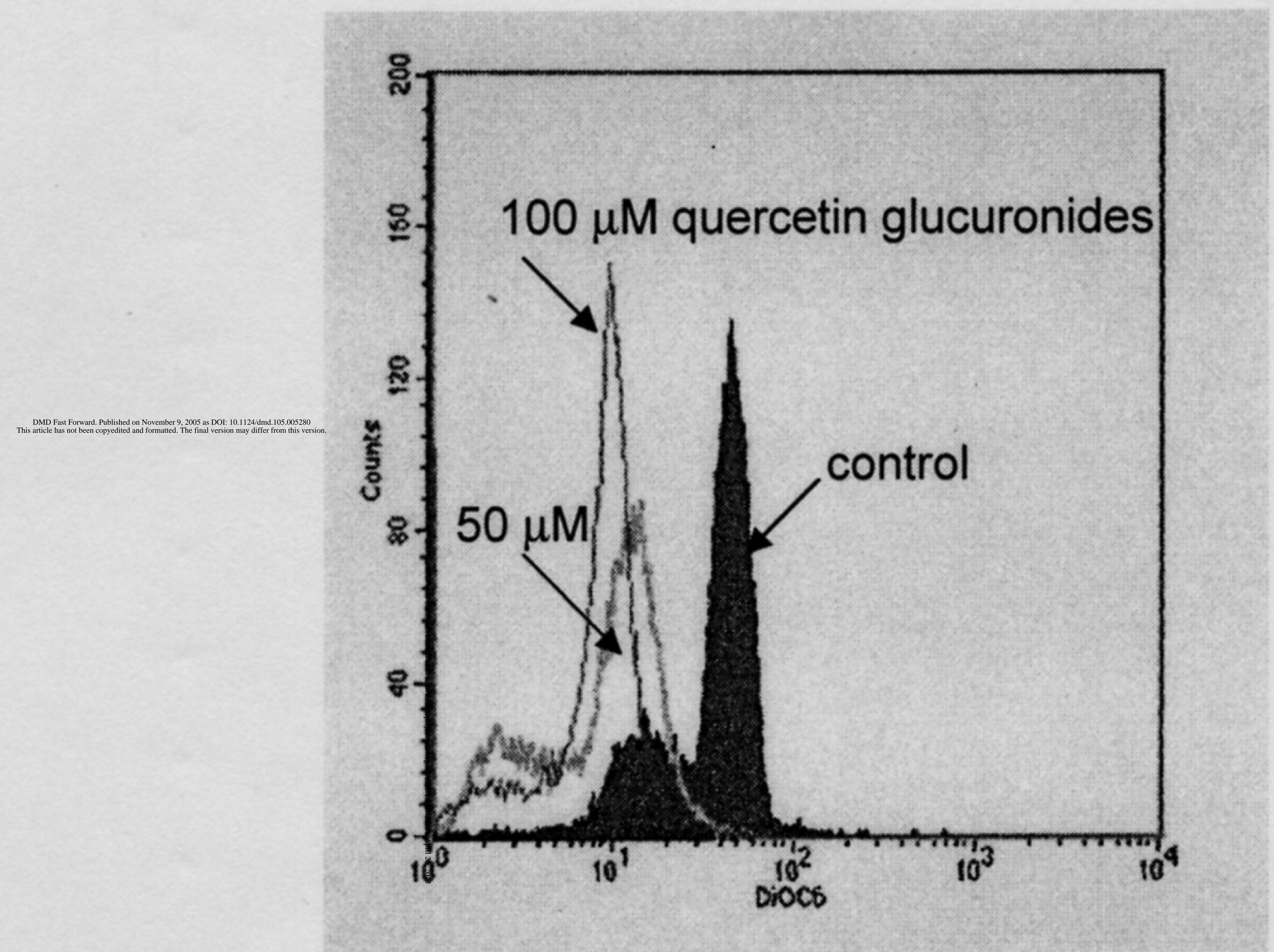


Fig. 6

\section{A}

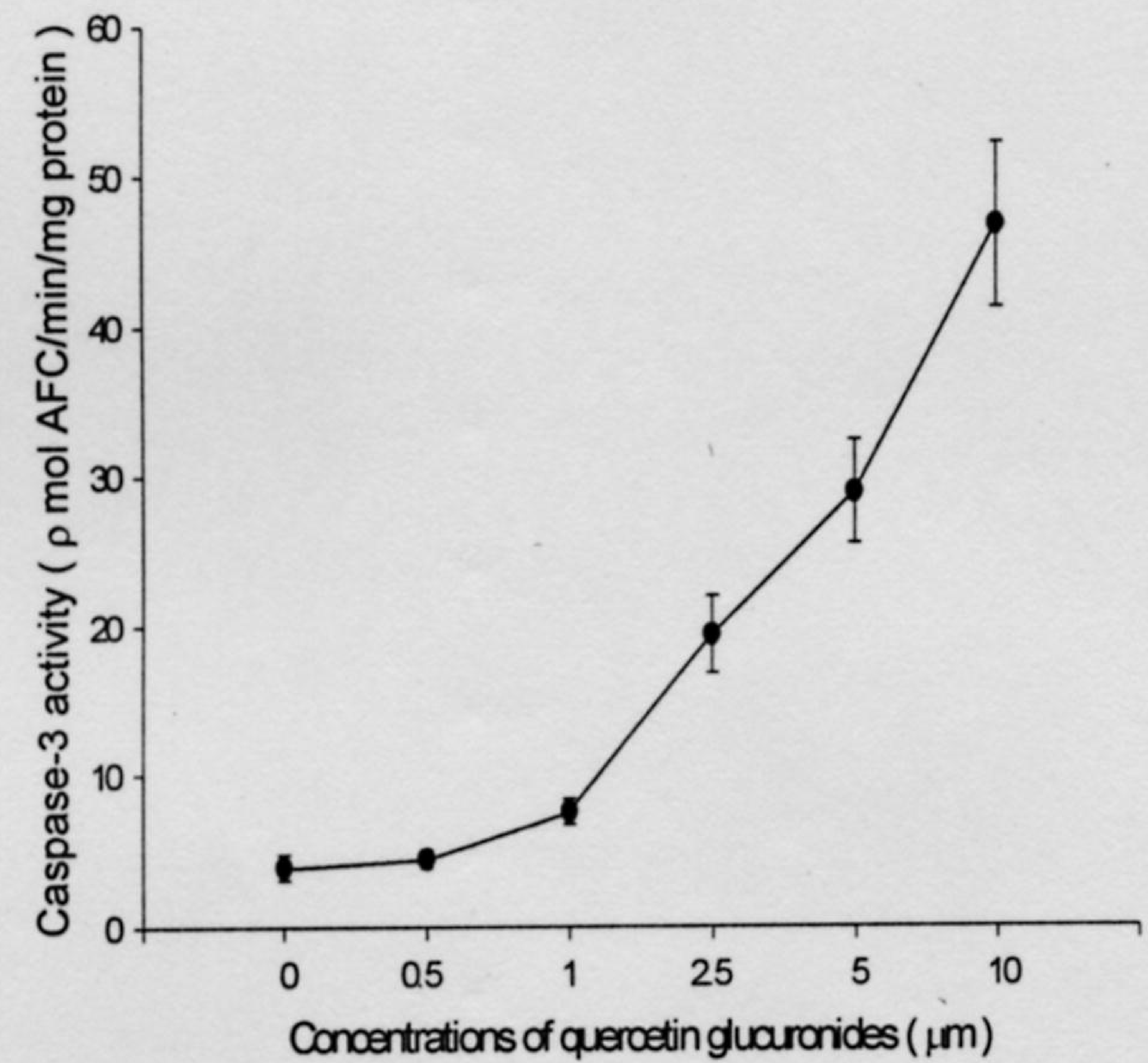

C

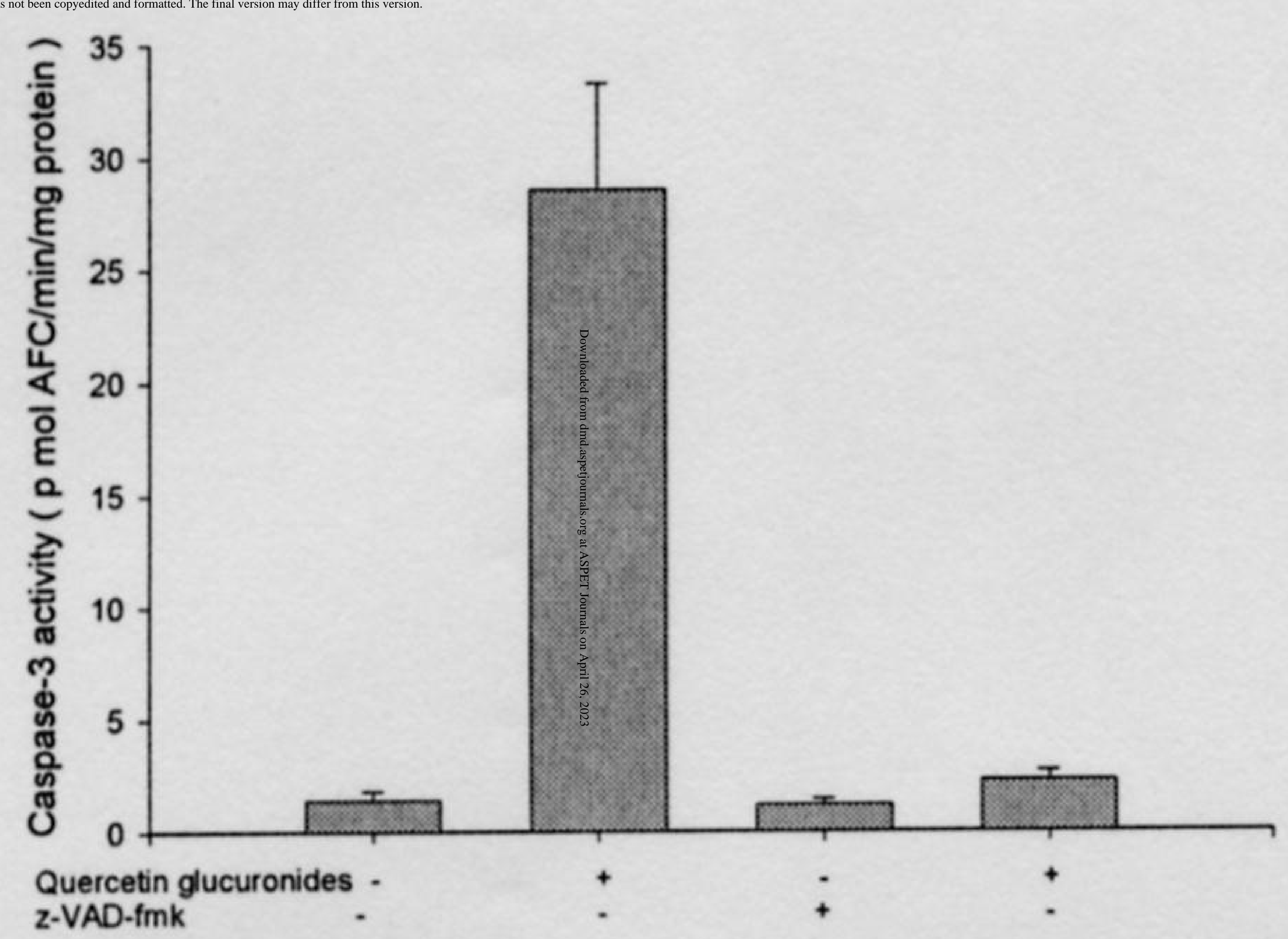

B

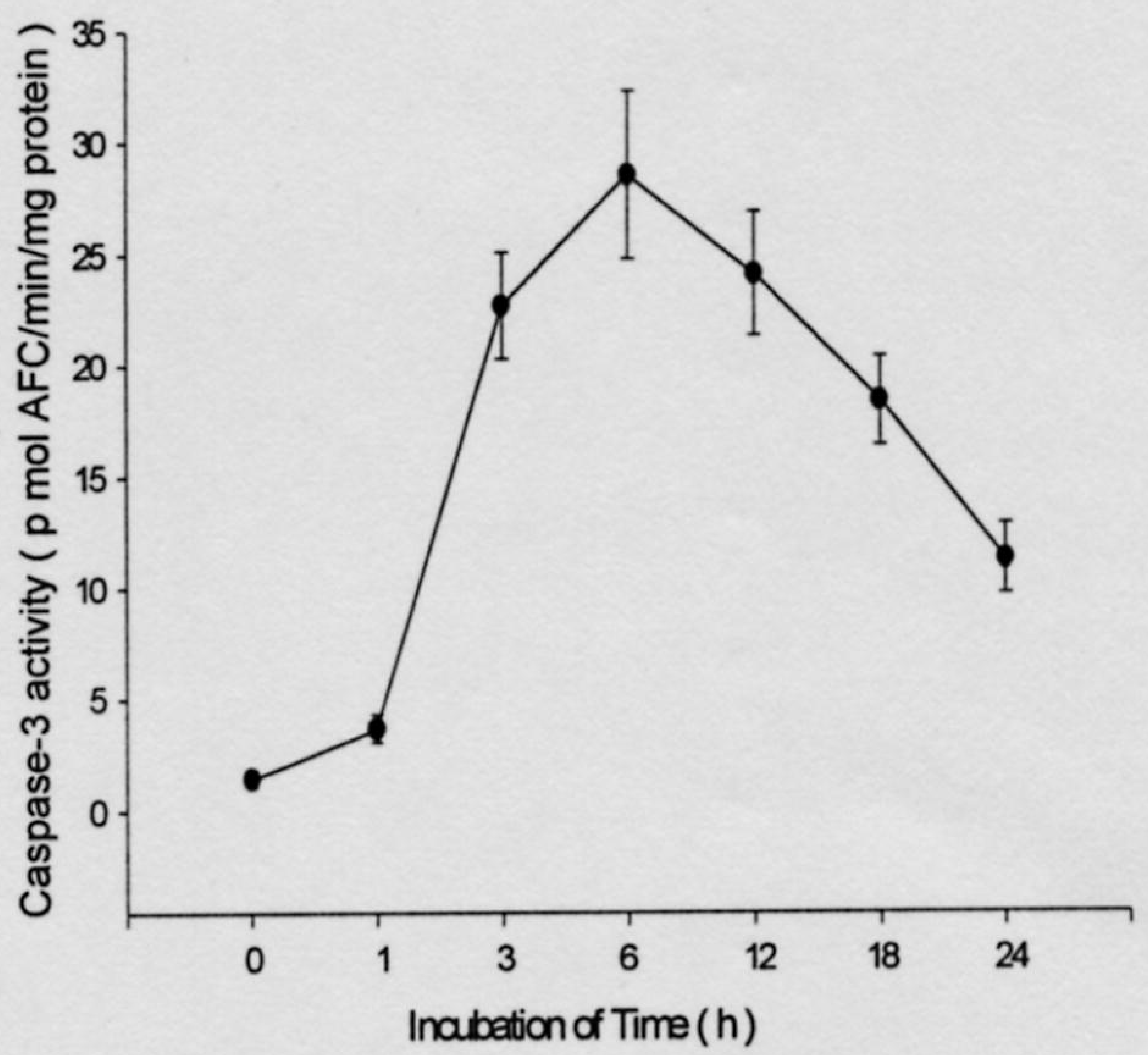

D

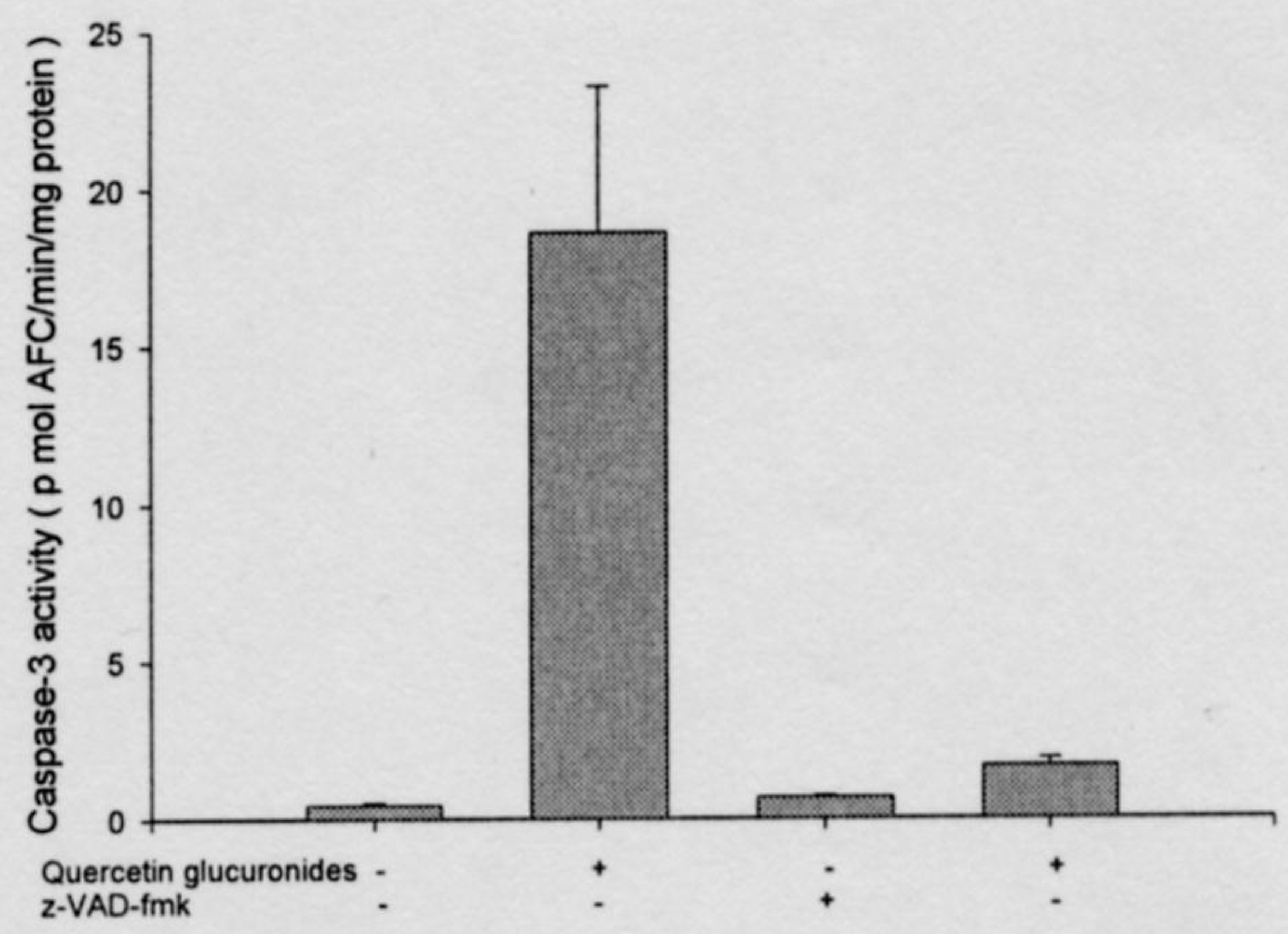


Fig. 7

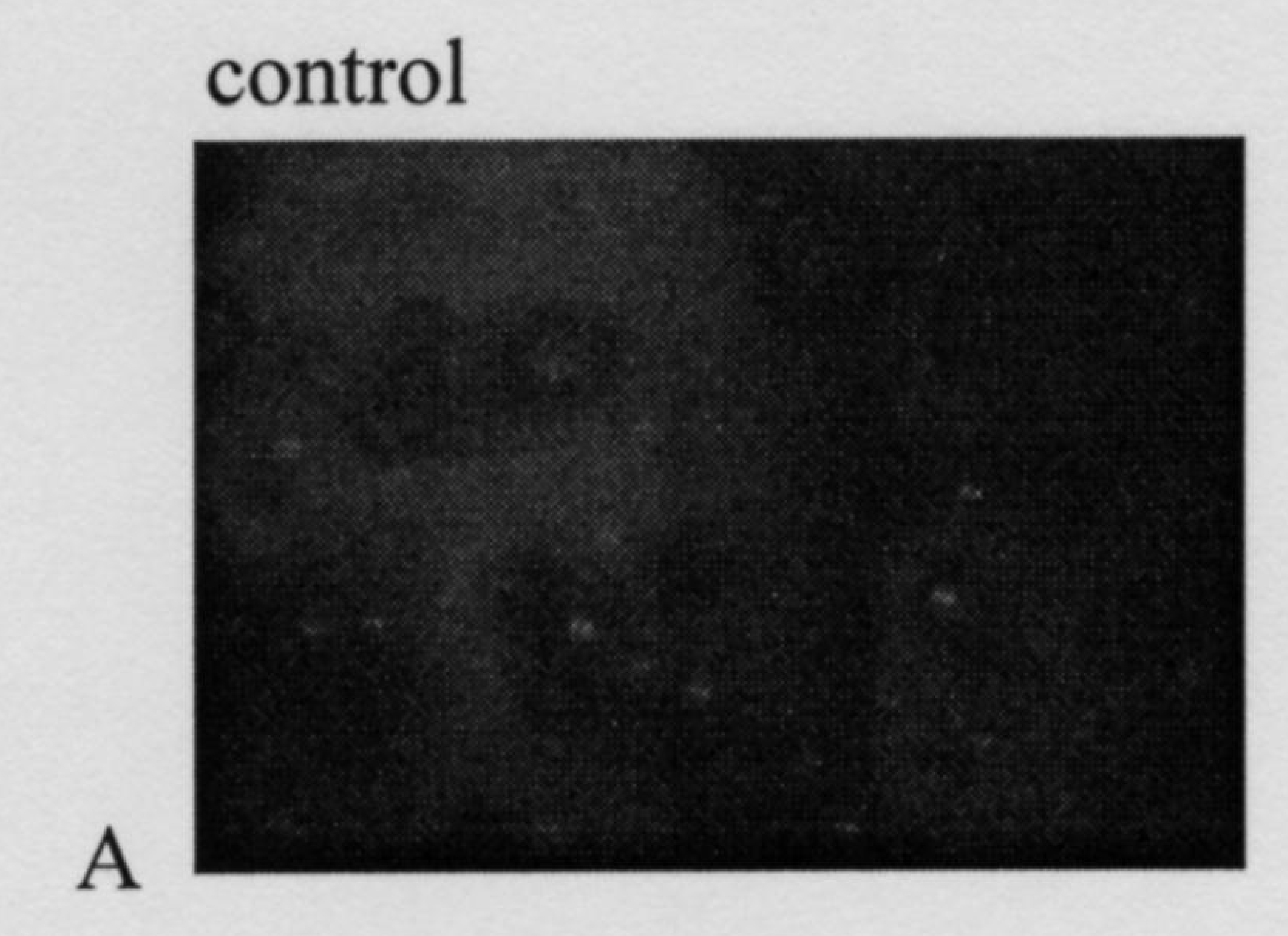

$1 \mu \mathrm{M}$ quercetin glucuronides

C

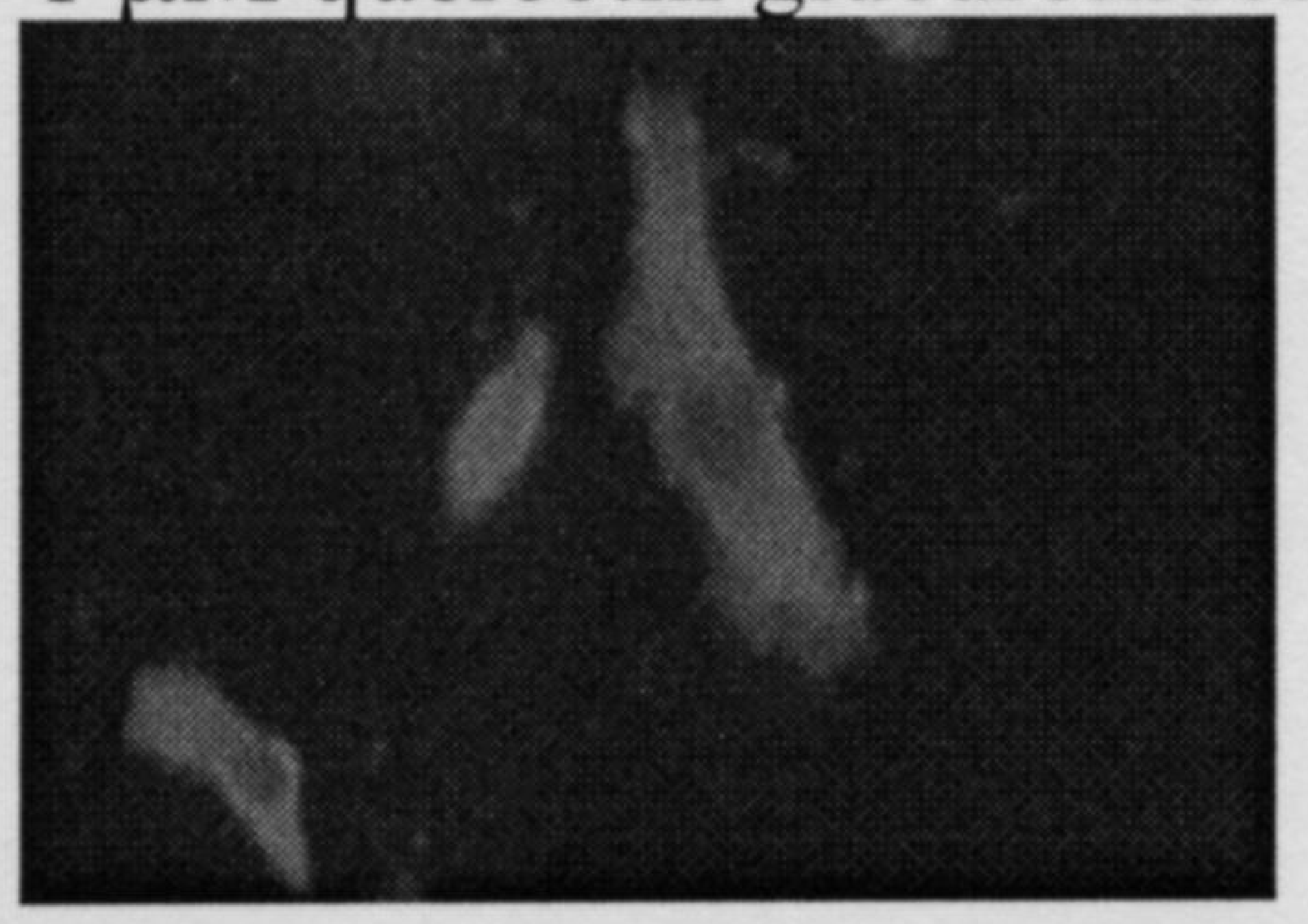

$5 \mu \mathrm{M}$ quercetin glucuronides

E

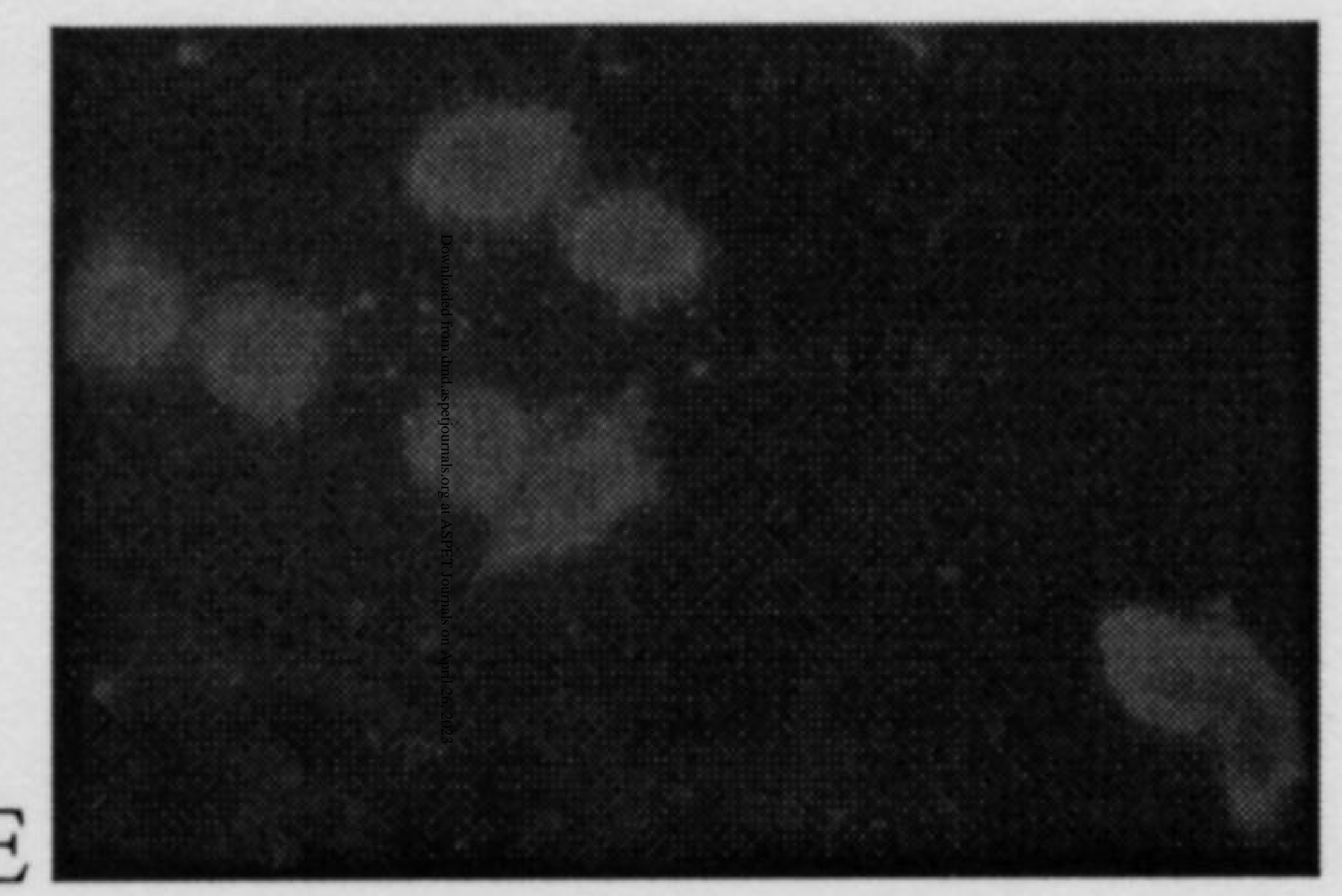

$0.5 \mu \mathrm{M}$ quercetin glucuronides

B

$2.5 \mu \mathrm{M}$ quercetin glucuronides

D

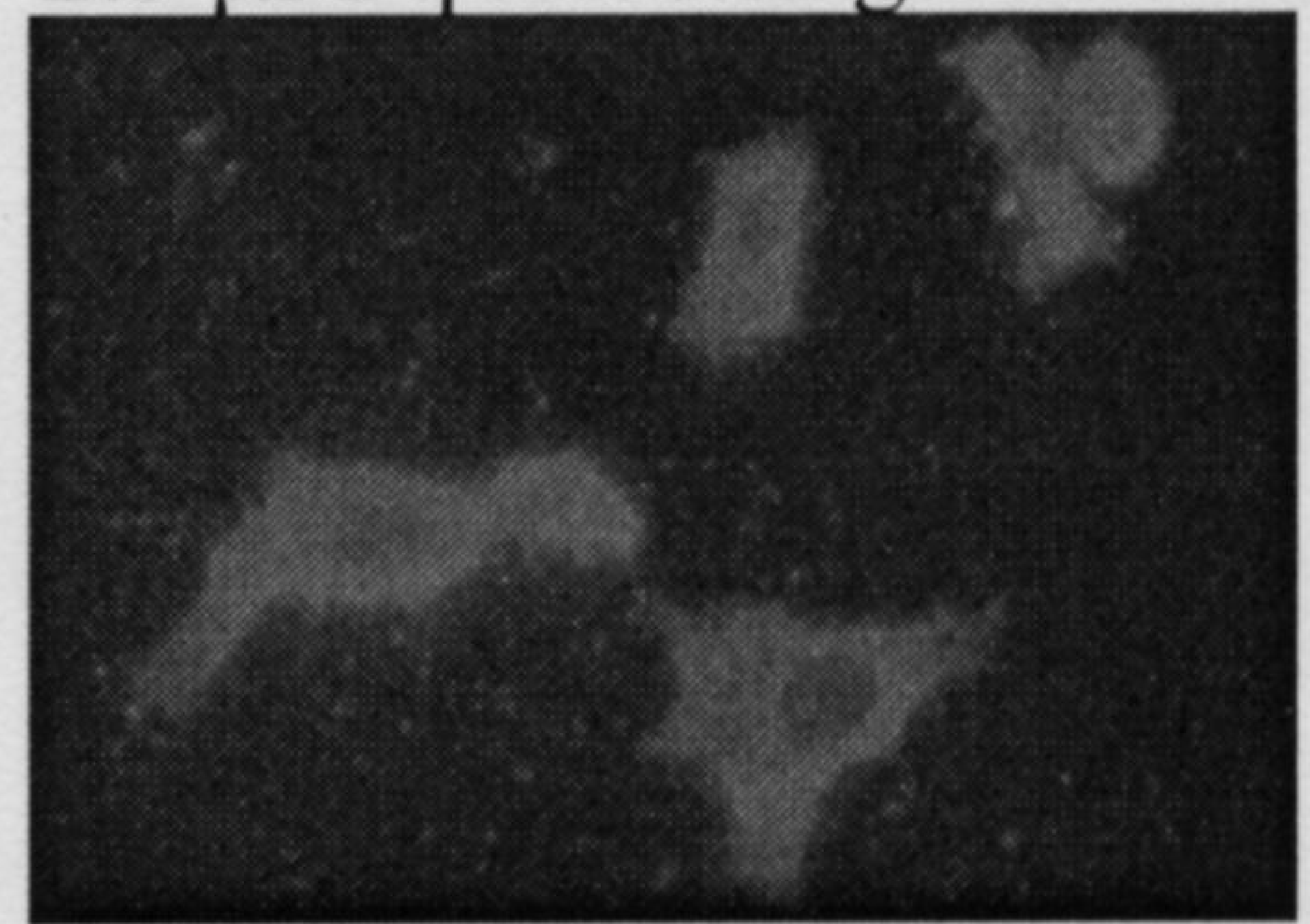

$10 \mu \mathrm{M}$ quercetin glucuronides

F

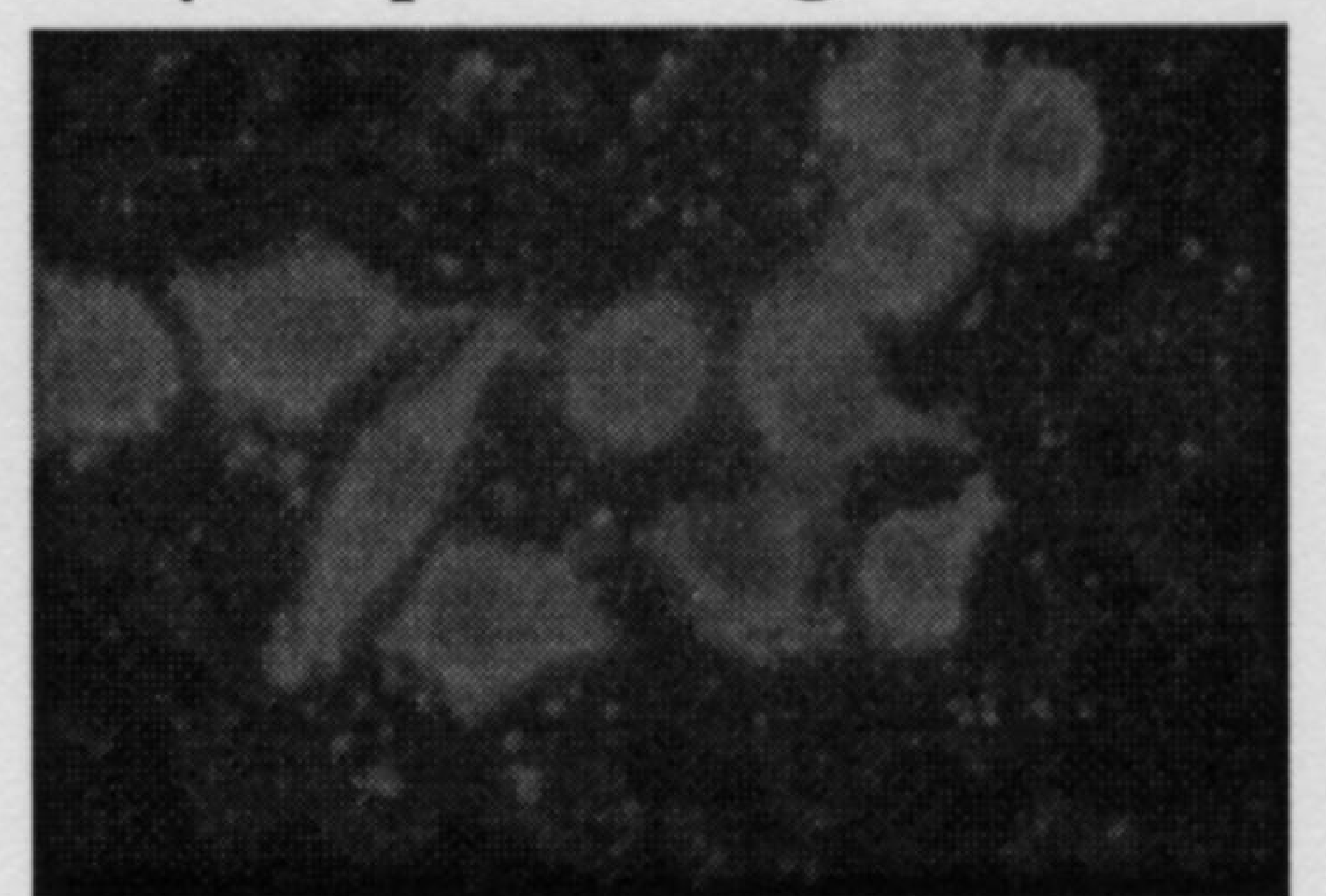


Fig. 8A

\section{Quercetin glucuronides $(\mu \mathrm{M})$}

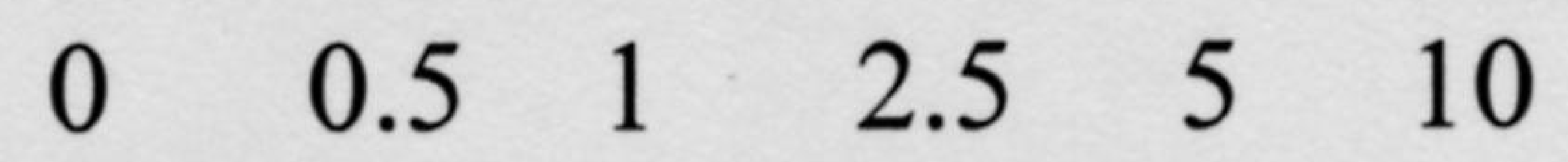

$\mathrm{p} 21^{\mathrm{CIP} 1 / \mathrm{WAF} 1}$

$\beta-\operatorname{actin}$

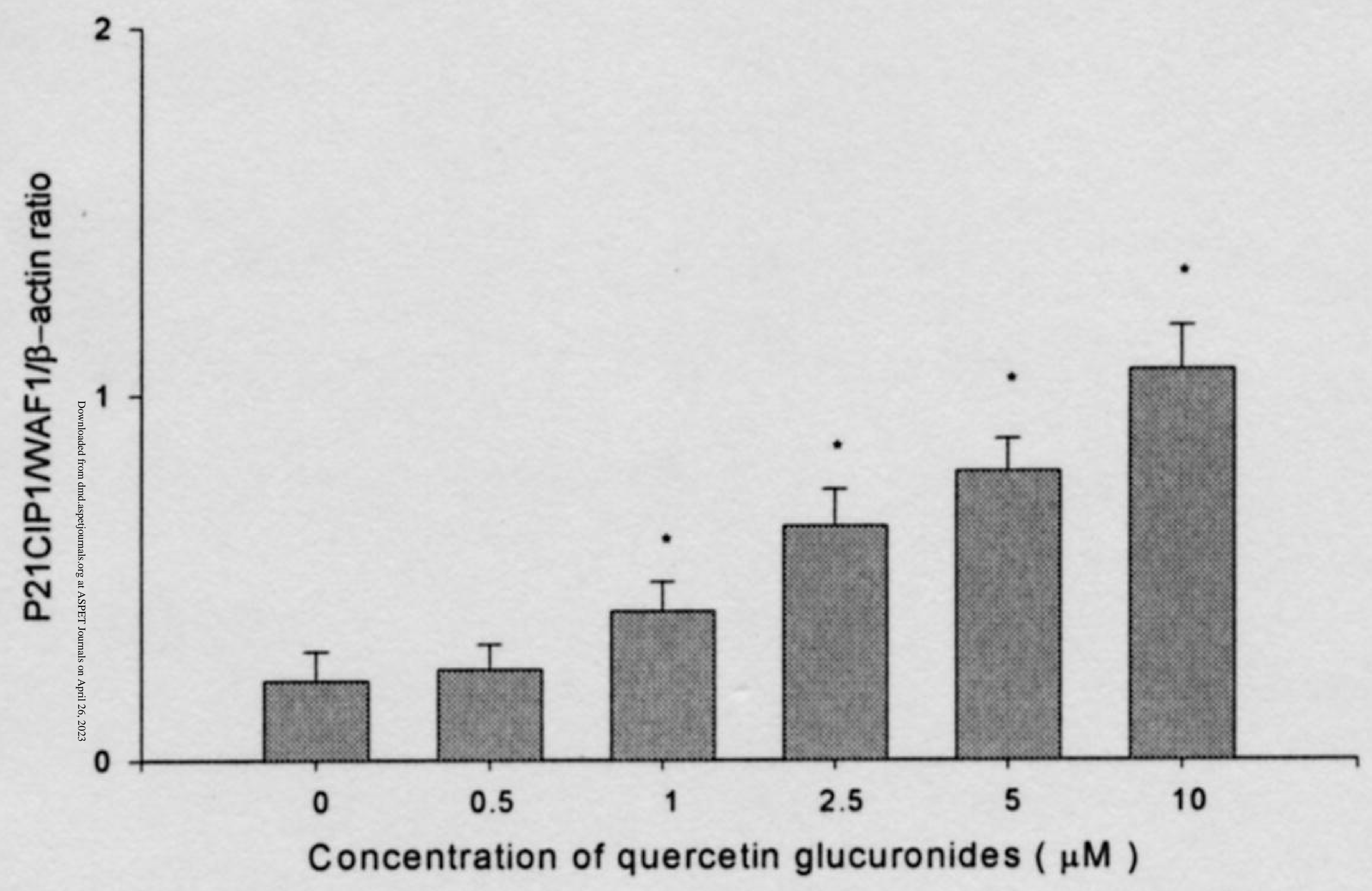


Fig. 8B
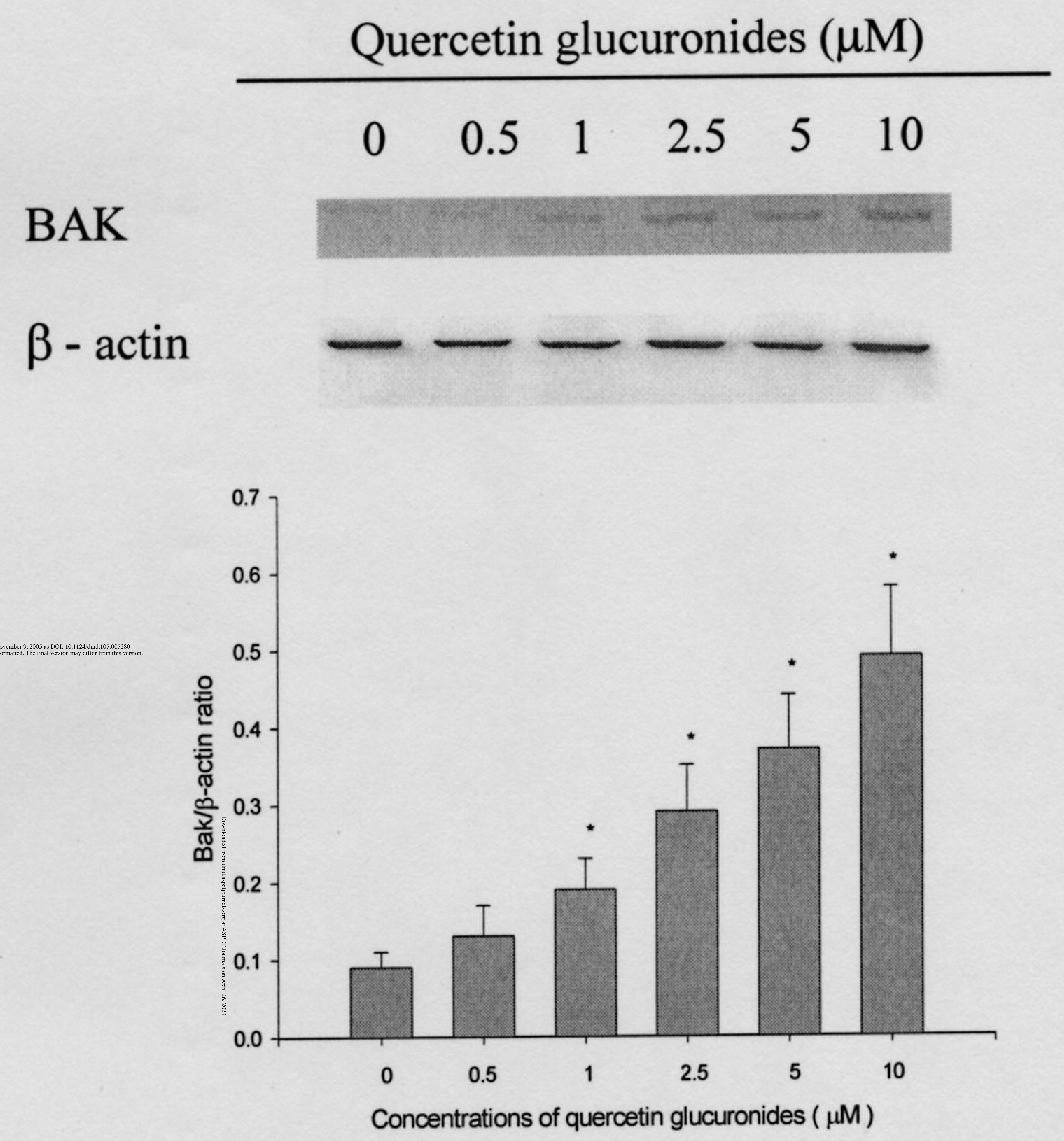
Fig. $8 \mathrm{C}$
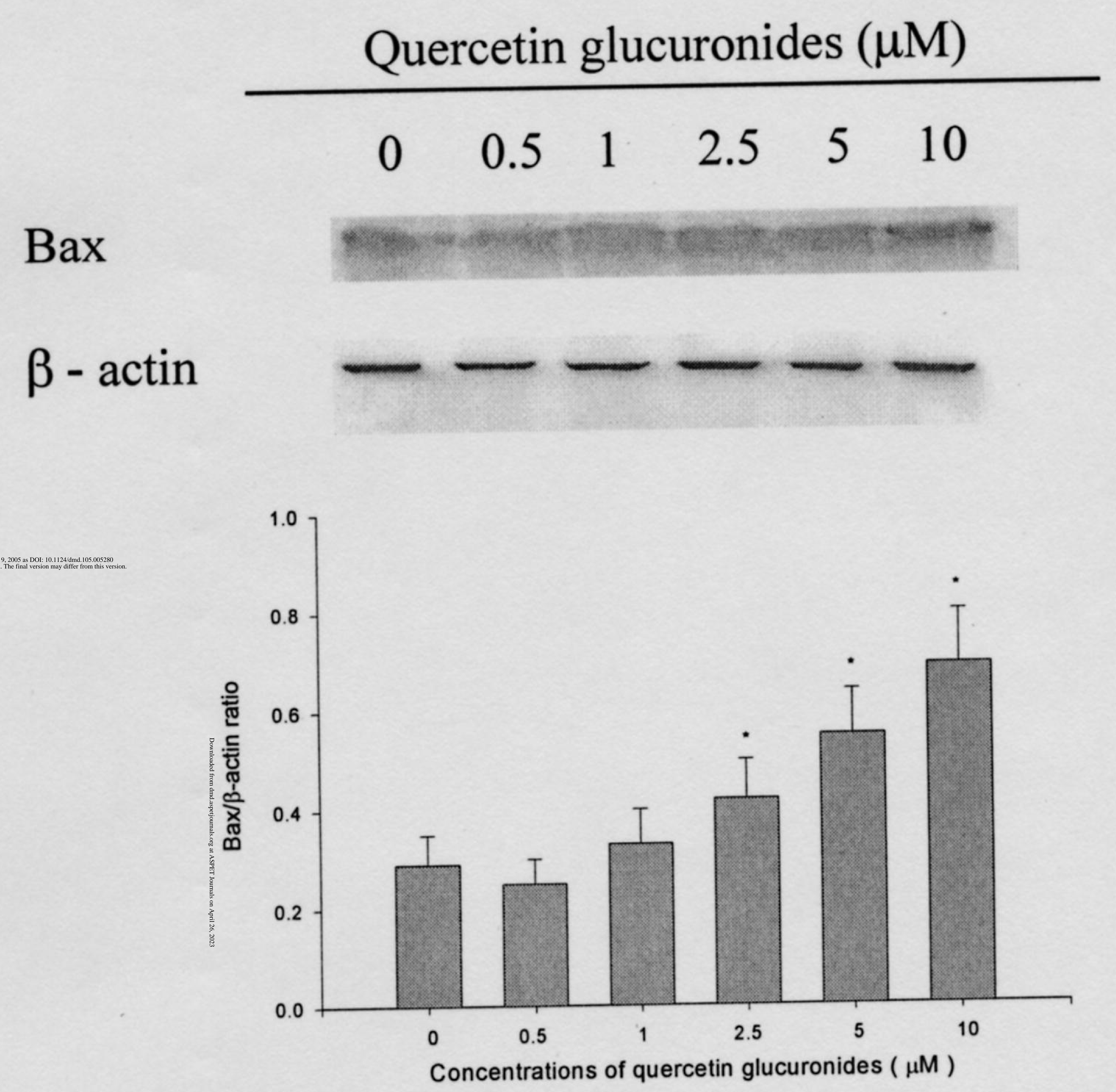
Fig. 8D
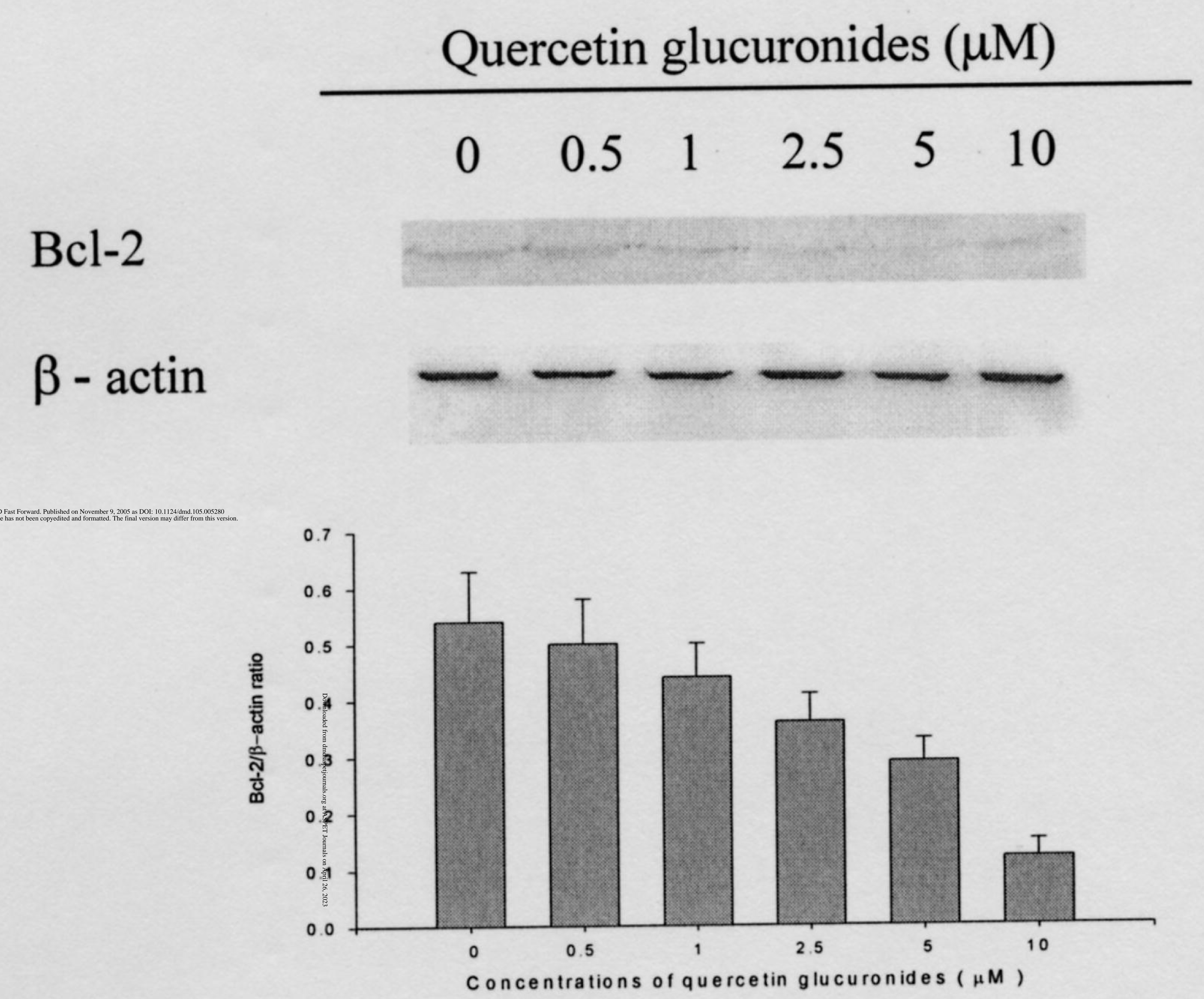
Fig. 8E

\section{Quercetin glucuronides $(\mu \mathrm{M})$}

\section{$\begin{array}{llllll}0 & 0.5 & 1 & 2.5 & 5 & 10\end{array}$}

\section{Cytochrome $c$}

$\beta-\operatorname{actin}$

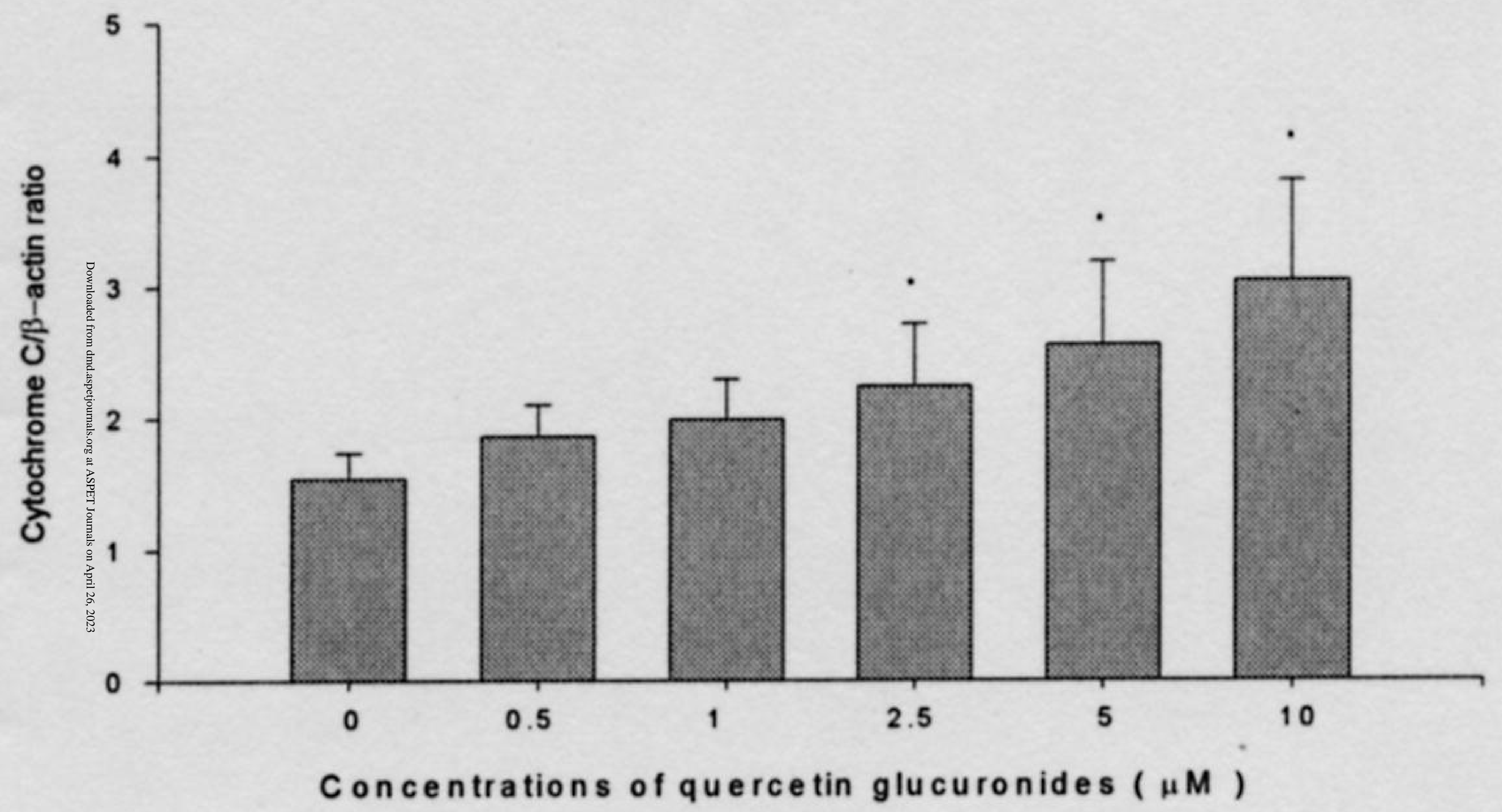


Fig. $8 \mathrm{~F}$

Quercetin glucuronides $(\mu \mathrm{M})$

$\begin{array}{llllll}0 & 0.5 & 1 & 2.5 & 5 & 10\end{array}$

Pro-caspase 3

Caspase 3

$\beta-\operatorname{actin}$

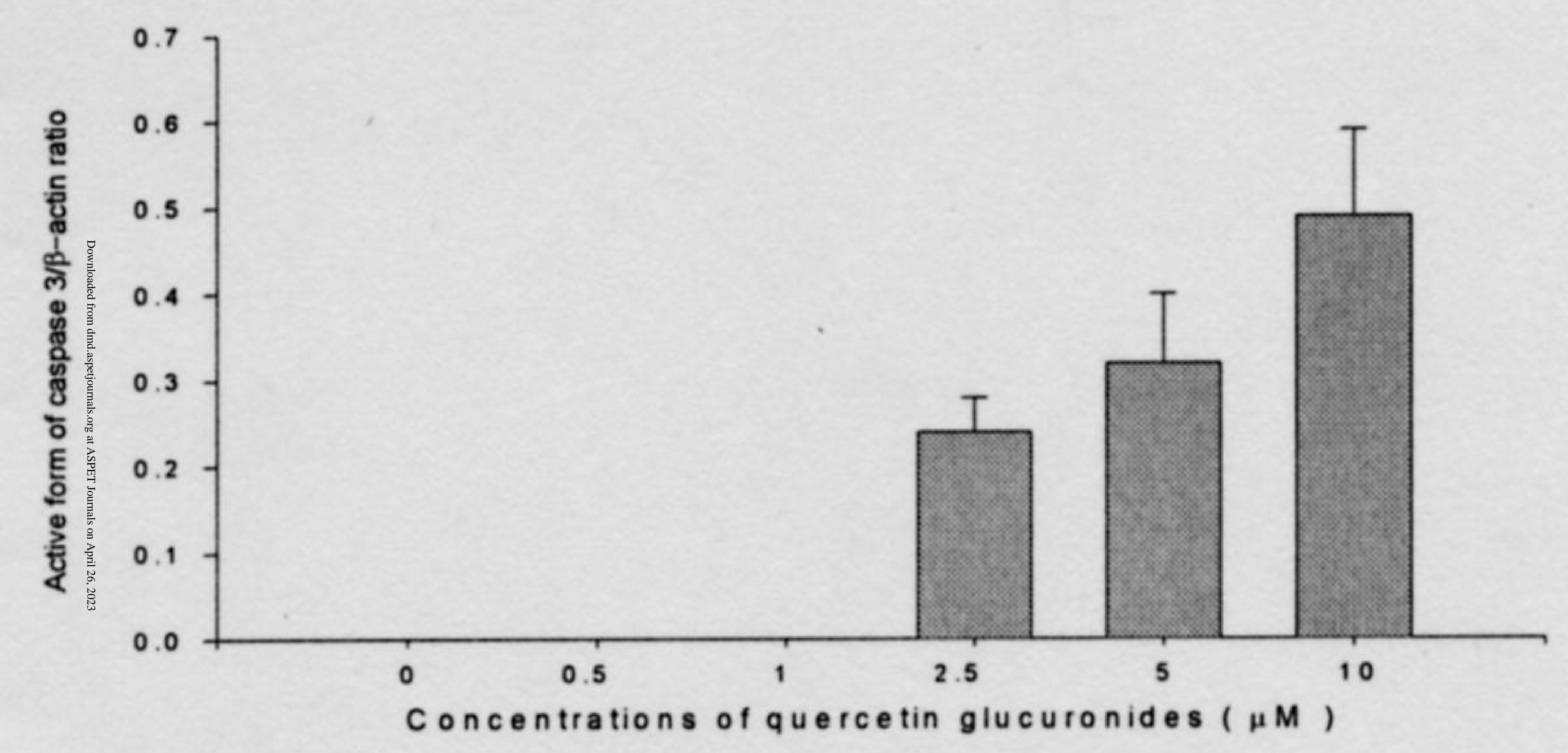

